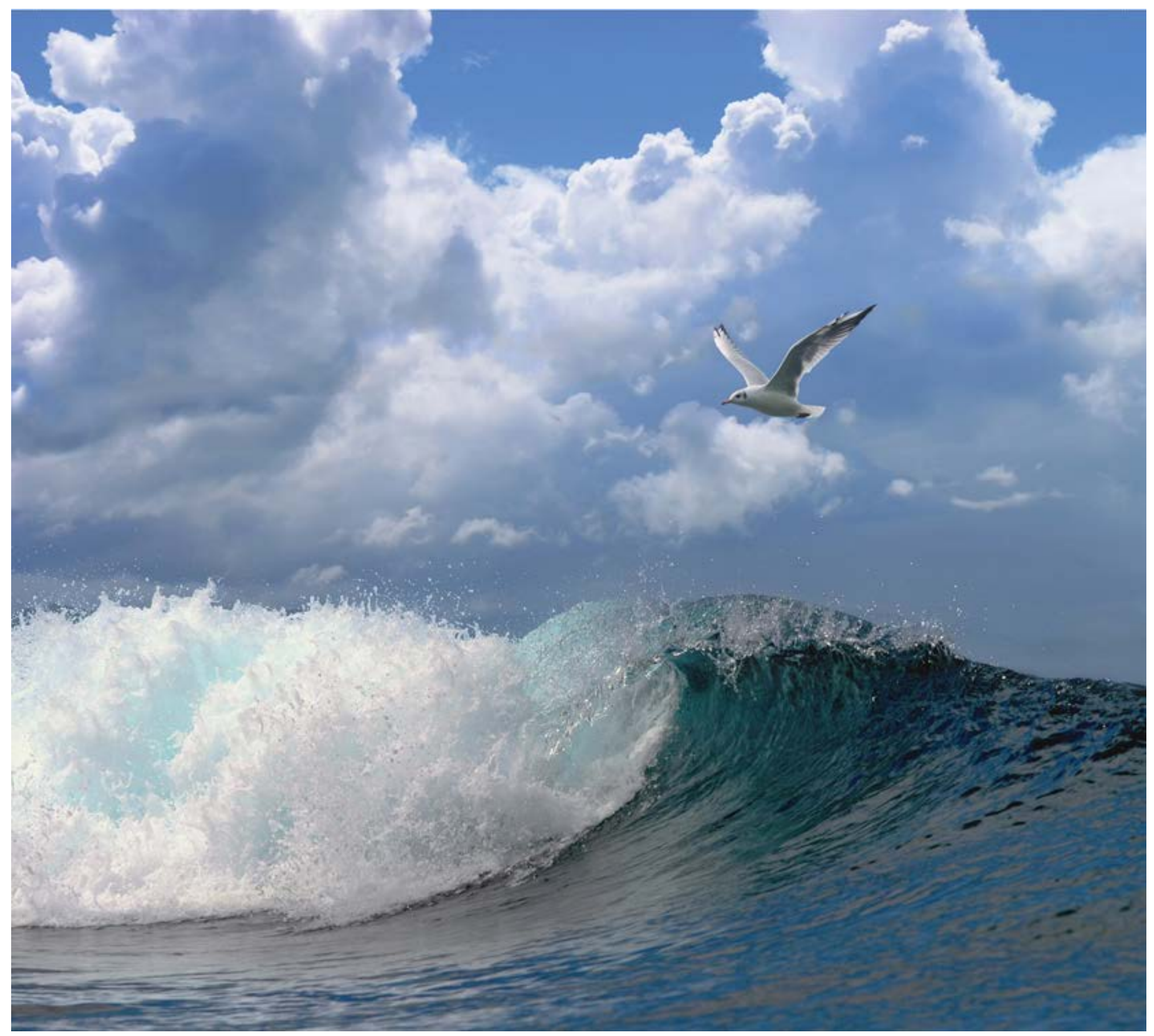

\title{
Habitatgeschiktheid van de Westerschelde voor de stekelrog (Raja clavata)
}




\section{Habitatgeschiktheid van de Westerschelde voor de stekelrog (Raja clavata)}

Auteur(s): $\quad$ H.V. Winter, R.H. Jongbloed

Publicatiedatum: 23 April 2018 
H.V. Winter, R.H. Jongbloed, 2018. Habitatgeschiktheid van de Westerschelde voor de stekelrog (Raja clavata). Wageningen Marine Research Wageningen UR (University \& Research centre), Wageningen Marine Research rapport C028/18. $37 \mathrm{blz}$

Keywords: herintroductie, habitat, verspreiding, abiotische factoren, vis survey, roggen.

Opdrachtgever: Sportvisserij Nederland \& Stichting De Noordzee

T.a.v.: drs. N.W.P. Brevé

Leijenseweg 115

3721 BC Bilthoven

Dit rapport is gratis te downloaden van https://doi.org/10.18174/447790

Wageningen Marine Research verstrekt geen gedrukte exemplaren van rapporten.

Wageningen Marine Research Wageningen UR is ISO 9001:2008 gecertificeerd.

(c) 2018 Wageningen Marine Research Wageningen UR

Wageningen Marine Research, onderdeel van Stichting Wageningen Research KvK nr. 09098104,

IMARES BTW nr. NL 8113.83.696.B16

Code BIC/SWIFT address: RABONL2U

IBAN code: NL 73 RABO 0373599285
De Directie van Wageningen Marine Research is niet aansprakelijk voor gevolgschade, noch voor schade welke voortvloeit uit toepassingen van de resultaten van werkzaamheden of andere gegevens verkregen van Wageningen Marine Research opdrachtgever vrijwaart Wageningen Marine Research van aanspraken van derden in verband met deze toepassing.

Dit rapport is vervaardigd op verzoek van de opdrachtgever hierboven aangegeven en is zijn eigendom. Niets uit dit rapport mag weergegeven en/of gepubliceerd worden, gefotokopieerd of op enige andere manier gebruikt worden zonder schriftelijke toestemming van de opdrachtgever. 


\section{Inhoud}

$\begin{array}{ll}\text { Summary } & 4\end{array}$

$1 \quad$ Inleiding $r$

1.1 Aanleiding en kennisvragen $\quad 5$

1.2 Afbakening $\quad 5$

$\begin{array}{lll}1.3 & \text { Aanpak } & 6\end{array}$

$\begin{array}{lll}1.4 & \text { Studiegebied Westerschelde } & 6\end{array}$

$\begin{array}{lll}1.5 & \text { Opbouw rapport } & 7\end{array}$

$2 \quad$ Biologie en habitateisen van de stekelrog (korte samenvatting) 8

3 Habitatkenmerken en -dynamiek van de Westerschelde in relatie tot geschiktheid voor de stekelrog

3.1 Waterdiepte $\quad 9$

$\begin{array}{ll}3.2 & \text { Sedimenttype } \\ 3.3 & \text { Bodemschufspanning }\end{array}$

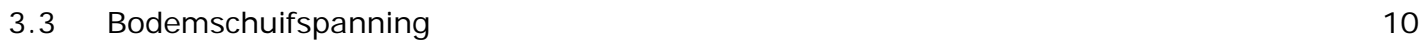

$\begin{array}{ll}3.4 & \text { Watertemperatuur } \\ 3.5 & 11\end{array}$

$\begin{array}{lll}3.5 & \text { Zoutgehalte } & 12\end{array}$

$\begin{array}{lll}3.6 & \text { Ontwikkelingen in waterkwaliteit } & 15\end{array}$

$\begin{array}{lll}3.7 & \text { Biotische factoren (voedselbeschikbaarheid) } & 16\end{array}$

3.8 Inschatting habitatgeschiktheid van de Westerschelde voor stekelrog 18

3.9 Inschatting van de migratie vanuit en bereikbaarheid van Westerschelde 18

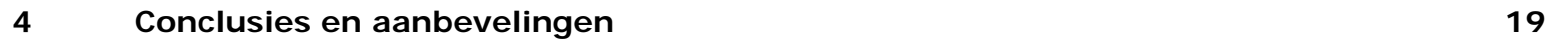

$\begin{array}{llr}4.1 & \text { Conclusies } & 19\end{array}$

$\begin{array}{ll}4.2 & \text { Aanbevelingen en overwegingen }\end{array}$

$\begin{array}{llr}5 & \text { Kwaliteitsborging } & 21\end{array}$

$\begin{array}{lr}\text { Literatuur } & 22\end{array}$

$\begin{array}{lr}\text { Verantwoording } & 24\end{array}$

$\begin{array}{lll}\text { Bijlage } 1 \quad \text { I UCN/ SSC richtlijnen voor herintroductie van soorten } & 25\end{array}$

Bijlage 2 Biologie, verspreiding en habitat- eisen van stekelrog 27 


\section{Summary}

In this report the suitability of the Westerschelde estuary for the thornback ray (Raja clavata) is discussed. For this, we used the literature review and data analysis of a suitability study of the Oosterschelde and the Voordelta that was carried out by Wageningen Marine Research in 2017. We then related these outcomes to environmental conditions occurring in the Westerschelde and discussed the suitability of the Westerschelde for the different life stages of thornback ray.

This study was performed within the program 'Sharks and rays back in the North Sea' of the Dutch World Wildlife Fund (WNF), Blue Linked, Stichting de Noordzee, the Dutch Shark Society and the Dutch Anglers Association (Sportvisserij Nederland). The program aims on ex-situ rearing of thornback rays that can be released into the wild. The most important questions are if thornback rays can fulfil at least part of their life cycle in the Westerschelde and what the connectivity to other marine habitats in the Southern North Sea are. This study will be used to assess the perspective of releasing thornback rays in the Westerschelde. The abundance of thornback ray in the southern North Sea has decreased during the 20th century. In recent years the abundance is stable to increasing. In this habitat suitability study habitat requirements of the thornback ray concerning abiotic and biotic factors are discussed.

Important abiotic environmental conditions that determine thornback ray abundance are depth, bed shear stress, temperature, salinity and sediment type. Juvenile thornback ray (0-1 group) and sub-adult and adult thornback ray (2+ group) are discussed separately because habitat requirements differ among these groups. Biotic factors like food availability are briefly discussed and probably not limiting in the studied areas. Other biotic factors like competition, predation, parasites and diseases are also important but knowledge on this in relation to thornback ray is very scarce and beyond the scope of this study.

The Westerschelde has a large variation of water depths up to $51 \mathrm{~m}$ meaning that suitable areas are available for all age classes. In the winter months water temperatures are too low for both age groups so that thornback rays can only seasonally use the Westerschelde during the main growing season and need to move to nearby wintering areas in the southern North Sea, as they do in the Thames Estuary. Bed shear stress in some of the deeper gullies are limiting factors especially for juvenile thornback rays, though there is sufficient area with lower bed shear present. With respect to salinity not much is known on the lower limit of salinity that thornback rays can still use. The Westerschelde has a strong gradient in salinity from Antwerp to Vlissingen that varies with river discharge of the Scheldt. In the Thames estuary thornback rays also enter the estuary, and show high relative abundance in those areas (especially juveniles). Adults might prefer habitats with somewhat higher salinities. Food availability (benthos) appears to improve over recent decades due to improvement of the quality of the water and sediments in the Westerschelde.

For juvenile thornback rays the western part of the Westerschelde (east from Terneuzen) appears most suitable in terms of water depth, sediment type and salinity. Within this area the area between Vlissingen-Terneuzen is very suitable in terms of bed shear stress. Whether they will also use habitats east from Terneuzen is unknown at present. For (sub) adults the areas around Vlissingen and to the west appear most suitable. The lower water temperatures in winter will make seasonal movement to wintering areas necessary, but these are available in the southern North Sea with unrestricted connectivity. It is possible that there are other unknown factors also determining the habitat quality for thornback ray, such as structures on the seafloor for disposal or attachment of egg cases.

Recommendations are presented to fill in knowledge gaps on the biology of the species, thus enabling to quantitatively predict the (relative) habitat suitability of the Westerschelde. With respect to release reared thornbacks we recommend to use juveniles and release them in the western part of the Westerschelde between Terneuzen and Vlissingen. When these are all tagged and partly also equipped with transmitters (e.g. acoustic and/or Data Storage tags) this will yield important new data on habitat use requirements of thornback rays and their movements between different habitats. 


\section{$1 \quad$ Inleiding}

\subsection{Aanleiding en kennisvragen}

In 2017 is er een habitatsgeschiktheidsanalyse voor stekelrog van de Oosterschelde en Voordelta uitgevoerd door Wageningen Marine Research (WMR). Dit in het kader van het programma 'Haaien en roggen terug in de Noordzee' (Jongbloed et al., 2017), een programma van het Wereld Natuur Fonds (WNF), Blue Linked, Stichting de Noordzee, de Dutch Shark Society en Sportvisserij Nederland (SVNL). Het project werkt met de ex-situ opkweek van stekelroggen die in het wild losgelaten worden. In aanvulling hierop heeft SVNL namens deze organisaties Wageningen Marine Research (WMR) verzocht om ook voor de Westerschelde de habitatgeschiktheid voor de stekelrog (Raja clavata) te beschouwen. De belangrijkste kennisvragen zijn (1) of stekelroggen in de Westerschelde een deel van hun levenscyclus zouden kunnen volbrengen en (2) of de connectiviteit met andere geschikte mariene habitats goed is. Deze studie wordt gebruikt door de bovengenoemde organisaties om duidelijkheid te krijgen over het perspectief van het uitzetten van gekweekte stekelroggen (Figuur 1.1) in de Westerschelde als bijdrage aan de ontwikkeling van een duurzame stekelrogpopulatie in de kustgebieden van de zuidelijke Noordzee. Decaantallen en de verspreiding van de stekelrog in de zuidelijke Noordzee is afgenomen in de loop van de afgelopen eeuw (ICES, 2016; Squotti et al., 2016).

Voortbordurend op de in 2017 uitgevoerde habitatgeschiktheidsanalyse die voor de Oosterschelde en Voordelta is uitgevoerd, waarin op basis van literatuuronderzoek en verspreidingsdata is geïnventariseerd welke eisen de stekelrog stelt aan zijn leefomgeving, wordt in deze rapportage beschouwd in hoeverre de omgevingsfactoren in de Westerschelde geschikt zijn voor juveniele en (sub) adulte stekelroggen. Antropogene effecten, bijvoorbeeld visserij en zandsuppleties, worden in dit rapport niet meegenomen. Met deze studie wordt aangesloten bij de IUCN Species Survival Commission (IUCN/SSC) richtlijnen voor herintroductie en andere beschermingsverplaatsingen van soorten (IUCN/SSC, 2013) (zie Bijlage 1).

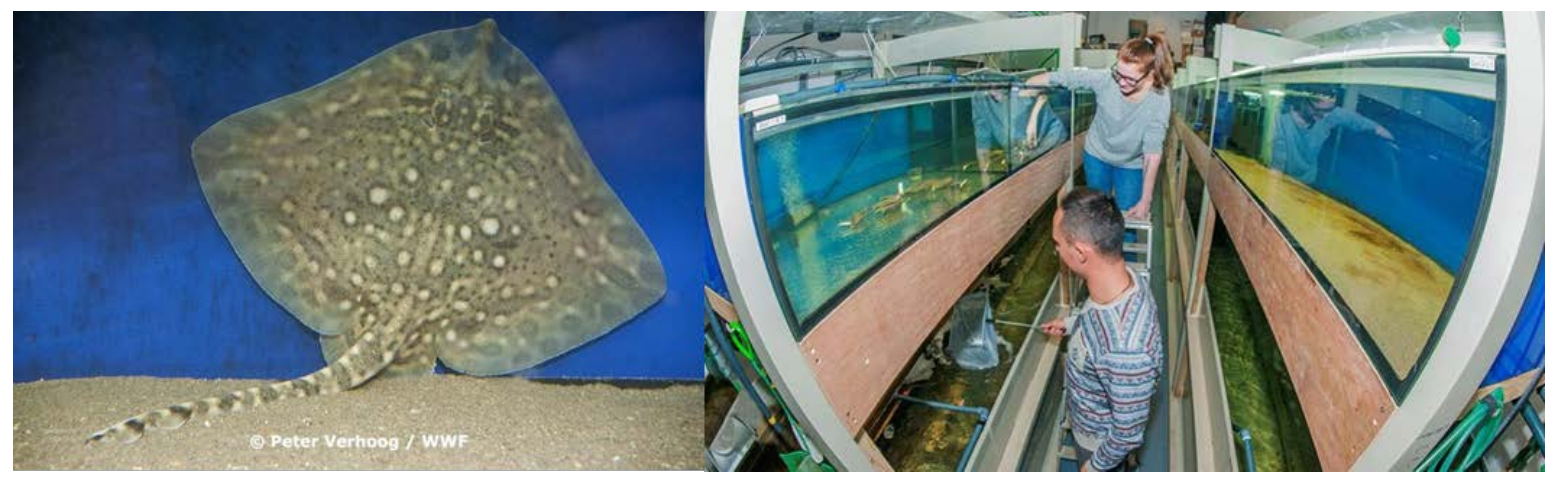

Figuur 1.1. Stekelrog (links) in het laboratorium van Blue Linked (Rechts). Foto's: P. Verhoog (WNF).

\subsection{Afbakening}

- In deze rapportage wordt geen advies over het wel of niet uitzetten van de gekweekte stekelroggen gegeven. Dat ligt buiten de reikwijdte van deze beschouwing van habitatgeschiktheid van de Westerschelde.

- Deze deskstudie is een eerste schatting van de habitatgeschiktheid voor de stekelrog en beperkt van omvang op basis van literatuur en data die in kader van de habitatsgeschiktheidsanalyse voor de Oosterschelde en Voordelta zijn verzameld (Jongbloed et al. 2017) en een quickscan van de abiotiek en dynamiek en enkele biotische factoren (gerelateerd aan voedselbeschikbaarheid) in de Westerschelde.

- De effecten van menselijke activiteiten zijn niet meegenomen in de deze beschouwing. 


\subsection{Aanpak}

Om de kennisvraag te beantwoorden, is de volgende werkwijze toegepast:

\begin{tabular}{|l|l|l|}
\hline Stap & Doel & Werkwijze \\
\hline 1 & $\begin{array}{l}\text { Inventariseren van de abiotische en } \\
\text { enkele voedsel gerelateerde biotische } \\
\text { habitatkenmerken van de Westerschelde }\end{array}$ & $\begin{array}{l}\text { Verzamelen van kaarten en gepubliceerde } \\
\text { gegevens en de extractie van abiotische } \\
\text { gegevens van bestaande datasets } \\
\text { (bijvoorbeeld RWS waterbase). }\end{array}$ \\
\hline 2 & $\begin{array}{l}\text { Inschatting van geschiktheid van de } \\
\text { habitats in de Westerschelde. }\end{array}$ & $\begin{array}{l}\text { Op basis van het literatuuronderzoek en } \\
\text { analyses uit Jongbloed et al. (2017) en } \\
\text { gegevens verzameld binnen stap 1. }\end{array}$ \\
\hline 3 & $\begin{array}{l}\text { Inschatting van de connectiviteit tussen } \\
\text { Westerschelde en andere voor stekelrog } \\
\text { geschikte zeehabitats. }\end{array}$ & $\begin{array}{l}\text { Op basis van literatuur en in stap 1 verzamelde } \\
\text { gegevens. }\end{array}$ \\
\hline
\end{tabular}

Deze deskstudie maakt gebruik van eerder literatuur- en bronnenonderzoek van J ongbloed et al. (2017) waarvoor gebruik is gemaakt van WMR-databases en diverse recente rapportages en wetenschappelijke publicaties aangevuld met literatuur en gegevens die betrekking hebben op de abiotische dynamiek en habitats in de Westerschelde en connectiviteit van de Westerschelde met andere mariene systemen.

\section{$1.4 \quad$ Studiegebied Westerschelde}

De Westerschelde is het studiegebied voor deze rapportage. Hierbij wordt het Nederlandse deel van de Westerschelde beschouwd (het Belgische zoete deel van de Schelde is niet relevant voor de stekelrog), en de connectiviteit van de Westerschelde met omliggende mariene habitats.

De Westerschelde is een open estuarium waar het rivierwater van de Schelde in uitmondt en naar de Noordzee stroomt (Figuur 1.2). Het is onderdeel van het Natura 2000-gebied 'Westerschelde en Saeftinghe' en kent een grote dynamiek in getijde, stromingspatronen, zoutgehalten en is een belangrijk gebied voor zowel natuur als menselijke activiteiten zoals scheepvaart. Er zijn droogvallende platen en slikken met zowel ondiep water als diepe stroomgeulen tot $51 \mathrm{~m}$ diepte. De afstand van de Belgische grens (Zeeschelde) tot de monding van de Westerschelde bedraagt circa $95 \mathrm{~km}$.

De Westerschelde is een zeer dynamisch systeem, waarin platen en geulen continu verschuiven. De instroom van zoet water vanuit de Schelde is gemiddeld $105 \mathrm{~m}^{3} /$ seconde, en het getijvolume ongeveer $109 \mathrm{~m}^{3}$ (Meire e.a., 1991). Het getijverschil in de Westerschelde ligt tussen de 3,8-5,2 m (Tabel 1), met een hoger getijverschil stroomopwaarts (Meire et al, 1991). In de Westerschelde wordt de hoogste biomassa aangetroffen in het intergetijde deel (ondiepe gebied tussen laag en hoog water), waar een lagere stroomsnelheid heerst, en neemt de biomassa af naar de diepere delen, waar het harder stroomt (Craeymeersch, 1999; Ysebaert et al., 2003; Ysebaert et al., 2009). 


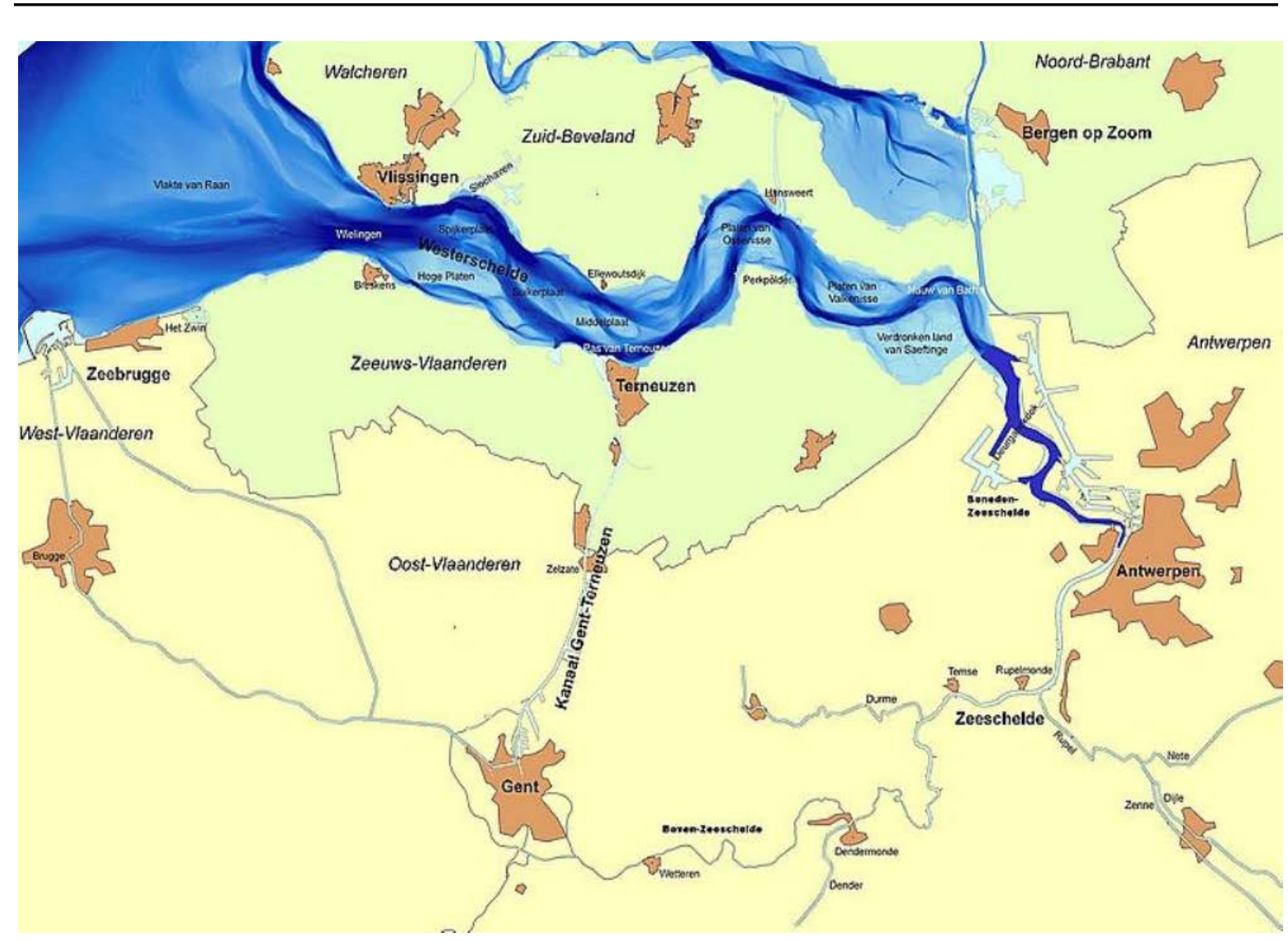

Figuur 1.2. Overzichtskaart van de Westerschelde en het stroomgebied van de Schelde met de stroomgeulen en belangrijkste plaatsen zoals genoemd in dit rapport (Schoevers, 2013).

\subsection{Opbouw rapport}

In hoofdstuk 2 wordt een kort overzicht van de biologie en habitatseisen van de stekelrog weergegeven gebaseerd op de studie van Jongbloed et al. (2017). In hoofdstuk 3 wordt de dynamiek in abiotische omgevingsfactoren en enkele biotische factoren gerelateerd aan voedselbeschikbaarheid voor stekelroggen in de Westerschelde. Tevens wordt in dit hoofdstuk een vergelijking tussen Westerschelde en Oosterschelde gemaakt. In hoofdstuk 4 wordt de habitatgeschiktheid en connectiviteit van de Westerschelde voor juveniele en (sub)adulte stekelrog beschouwd. Conclusies en aanbevelingen worden weergegeven in hoofdstuk 5.

In Bijlage 1 worden de IUCN richtlijnen voor herintroductie en andere beschermingsverplaatsingen van soorten samengevat. Bijlage 2 is overgenomen uit Jongbloed et al. (2017) en omwille van de zelfstandige leesbaarheid van deze rapportage hier ook ingevoegd. Deze bijlage geeft een overzicht van de biologie, verspreiding en ontwikkeling van de stekelrog in de zuidelijke Noordzee en omstreken. Daarnaast worden de resultaten van de literatuurstudie naar de habitateisen van stekelroggen in de Noordzee en enkele andere zeeën beschreven en geëvalueerd om te komen tot een set van algemeen geldende (geharmoniseerde) kennisregels voor de omgevingsfactoren die de habitateisen voor de stekelrog vormen. 


\section{Biologie en habitateisen van de stekelrog (korte samenvatting)}

Dit hoofdstuk is gebaseerd op de studie van Jongbloed et al. (2017). In Bijlage 1 is een weergave opgenomen van de biologie, verspreiding en habitateisen van de stekelrog zoals die door Jongbloed et al. (2017) is uitgevoerd.

Voor het voorkomen van stekelroggen zijn vijf abiotische omgevingsfactoren als belangrijk gekwalificeerd. De tolerantie en de voorkeur van de stekelrog voor deze factoren zijn hierbij ingeschat op basis van literatuur en beschikbare data (die relatief schaars is) wat resulteerde in een overzichtstabel met ranges waarbinnen het habitat geschikt wordt geacht voor de stekelrog (zie Bijlage 1, tabel B.3). Voor de abiotische factoren was de inschatting dat dit redelijk in kaart is te brengen. Dat geldt echter niet voor de biotische factoren. Daarvoor kunnen met de huidige kennis nog geen tolerantiegrenzen worden gegeven (Jongbloed et al. 2017).

Tabel 2.1 Belangrijke abiotische factoren voor geschiktheid van habitats voor stekelroggen (uit: J ongbloed et al. 2017)

\begin{tabular}{|l|l|}
\hline Factoren & Geschiktheid voor stekelrog \\
\hline Diepte & $\begin{array}{l}\text { Brede range en leeftijdsafhankelijk: ondiep voor juvenielen en dieper (tot } 40 \mathrm{~m} \text { en } \\
\text { tot } 82 \mathrm{~m} \text { ) voor adulten. In Noordzee seizoensafhankelijk: dieper (20-35 m) gedurende } \\
\text { herfst en winter; ondieper (<20 m) gedurende voorjaar en zomer. }\end{array}$ \\
\hline $\begin{array}{l}\text { Bodemschuifspanning } \\
\text { (stroming en golven) }\end{array}$ & $\begin{array}{l}\text { Brede range en leeftijdsafhankelijk van zwak (juvenielen) tot intermediair tot sterke } \\
\text { getijdestromingen (adulten) (Martin et al. 2012). Tussen } 0 \text { en } 1.5 \mathrm{~N} / \mathrm{m}^{2} \text { (Maxwell et } \\
\text { al., 2009). }\end{array}$ \\
\hline Saliniteit & $\begin{array}{l}\text { Vrij brede range inclusief } 32,4-34,9 \mathrm{ppt}, \text { waarbij met name juveniele stekelroggen } \\
\text { ook habitats met lagere zoutgehalten kunnen benutten*. }\end{array}$ \\
\hline Watertemperatuur & $\begin{array}{l}\text { Hogere temperatuur in de range 9,5-19 }{ }^{\circ} \mathrm{C} . \text { Juvenielen prefereren hogere temp, dan } \\
\text { adulten. Anderzijds is temperatuur geen voorspeller volgens Humphries et al. (2016). }\end{array}$ \\
\hline Sediment type & $\begin{array}{l}\text { Brede range (slib, fijn zand, grof zand, gravel, kiezel) en leeftijdsafhankelijk van slib } \\
\text { en zandig (juvenielen) tot gravel en kiezels (ad.) en afhankelijk van visserijdruk. }\end{array}$ \\
\hline
\end{tabular}

* De tekst uit de oorspronkelijke tabel is iets uitgebreid met bevindingen uit dezelfde rapportage over gebruik van lagere zoutgehalten (Jongbloed et al. 2017), in hoofdstuk 3 zal hier verder op in worden gegaan. 


\section{Habitatkenmerken en -dynamiek van de Westerschelde in relatie tot geschiktheid voor de stekelrog}

Uit de habitatgeschiktheidsanalyse van J ongbloed et al. (2017) komen vijf abiotische omgevingsfactoren naar voren die belangrijk zijn: waterdiepte, sedimenttype, bodemschuifspanning, zoutgehalte en watertemperatuur. Daarnaast wordt ook de ontwikkeling van de waterkwaliteit van de Schelde en Westerschelde kort beschouwd omdat deze wellicht ook beperkend zou kunnen zijn voor de geschiktheid van de stekelrog. Deze abiotische factoren en de dynamiek hierin voor de Westerschelde worden hieronder weergegeven en aangevuld met een korte beschouwing van enkele biotische factoren die gerelateerd zijn aan de voedselbeschikbaarheid van de stekelrog.

\subsection{Waterdiepte}

De Westerschelde is een zeer dynamisch en gevarieerd stroomgebied die in diepte varieert tussen droogvallend getijdegebied tot -51 m NAP diep. Een kaart van de waterdiepte is te vinden in weergegeven in Figuur 3.1.

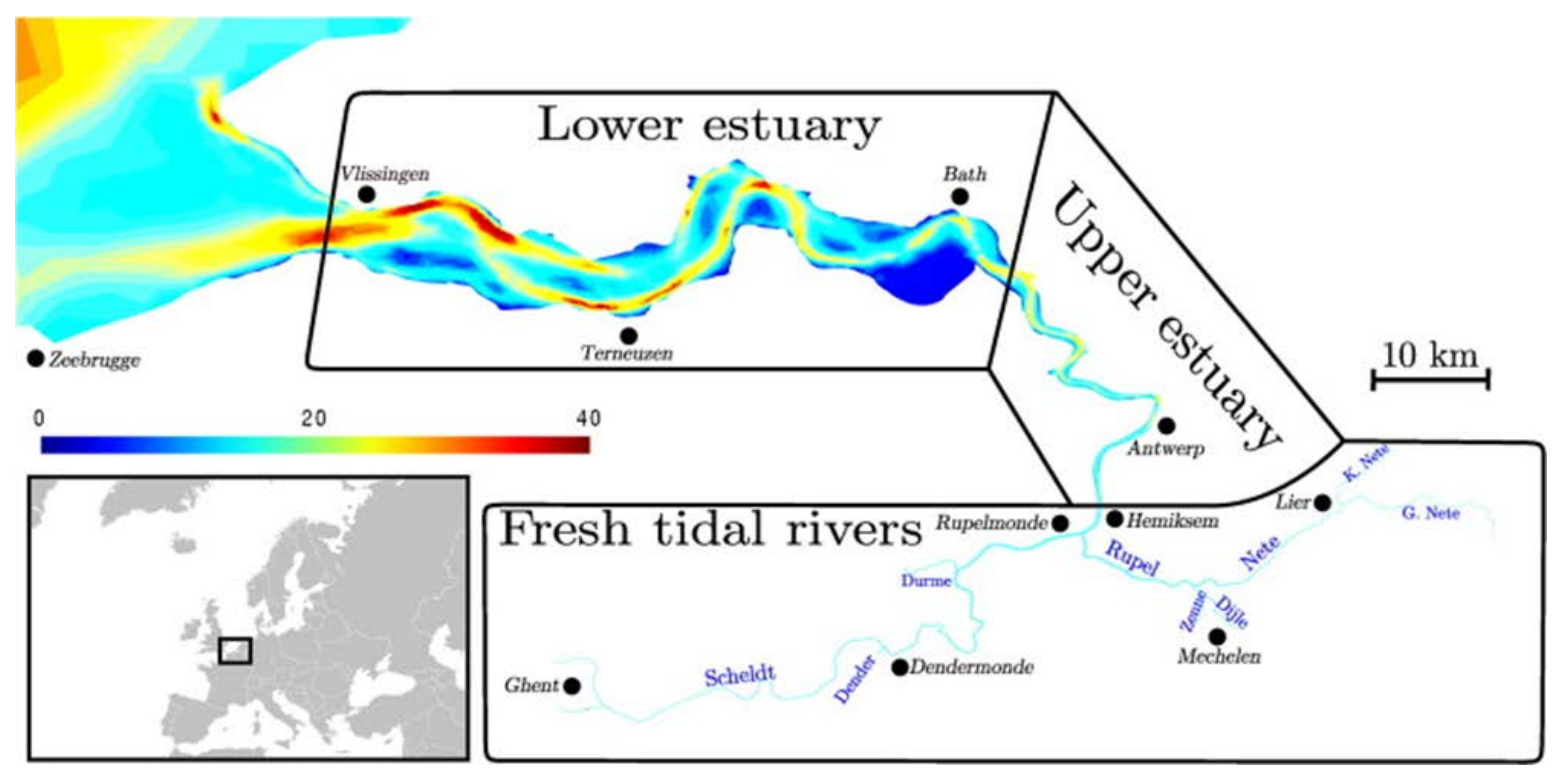

Figuur 3.1. Waterdiepte kaart van de Westerschelde (Lower estuary), Zeeschelde (Upper estuary) en Schelde (Fresh tidal rivers) (de Brye et al., 2010).

Door de grote variatie in waterdieptes zijn er zowel voor juveniele stekelroggen (die geringere waterdiepten prefereren) als voor (sub)adulte stekelroggen (die dieper water prefereren) geschikte dieptes aanwezig. Tussen de seizoenen kan de preferentie in benutte waterdiepte variëren tussen dieper (20-35m) gedurende herfst en winter en ondieper $(<20 \mathrm{~m})$ gedurende voorjaar en zomer. Ook dit diepere water is veel te vinden in de Westerschelde. Ondiep water is geschikt voor adulte stekelroggen wanneer ze zich voort willen planten en die gebieden komen in de Westerschelde ook voor. Waterdiepte in de Westerschelde zal geen beperkende factor zijn voor zowel juveniele als adulte stekelroggen. 


\subsection{Sedimenttype}

Stroomsnelheid is één van de belangrijkste sturende factoren voor de verspreiding van sedimenttypen in estuaria. Bij een hogere stroomsnelheid neemt het percentage grof zand in de bodem toe (Craeymeersch, 1999). Zones waar gedurende bepaalde tijd relatief hoge maximale stroomsnelheden voorkomen worden geclassificeerd als 'hoogdynamisch' en zones met lagere stroomsnelheden als 'laagdynamisch'. De stroomsnelheid neemt over het algemeen toe bij toenemende diepte. De stroomsnelheid in de Westerschelde is relatief hoog, vooral in de vaargeulen (Figuur 3.1). In de Westerschelde komen met name fijnere sedimenten voor van grof en fijn zand (vooral in ecotoop hoogdynamisch sublitoraal) tot slib (vooral in laagdynamisch sublitoraal), zie Figuur 3.2.

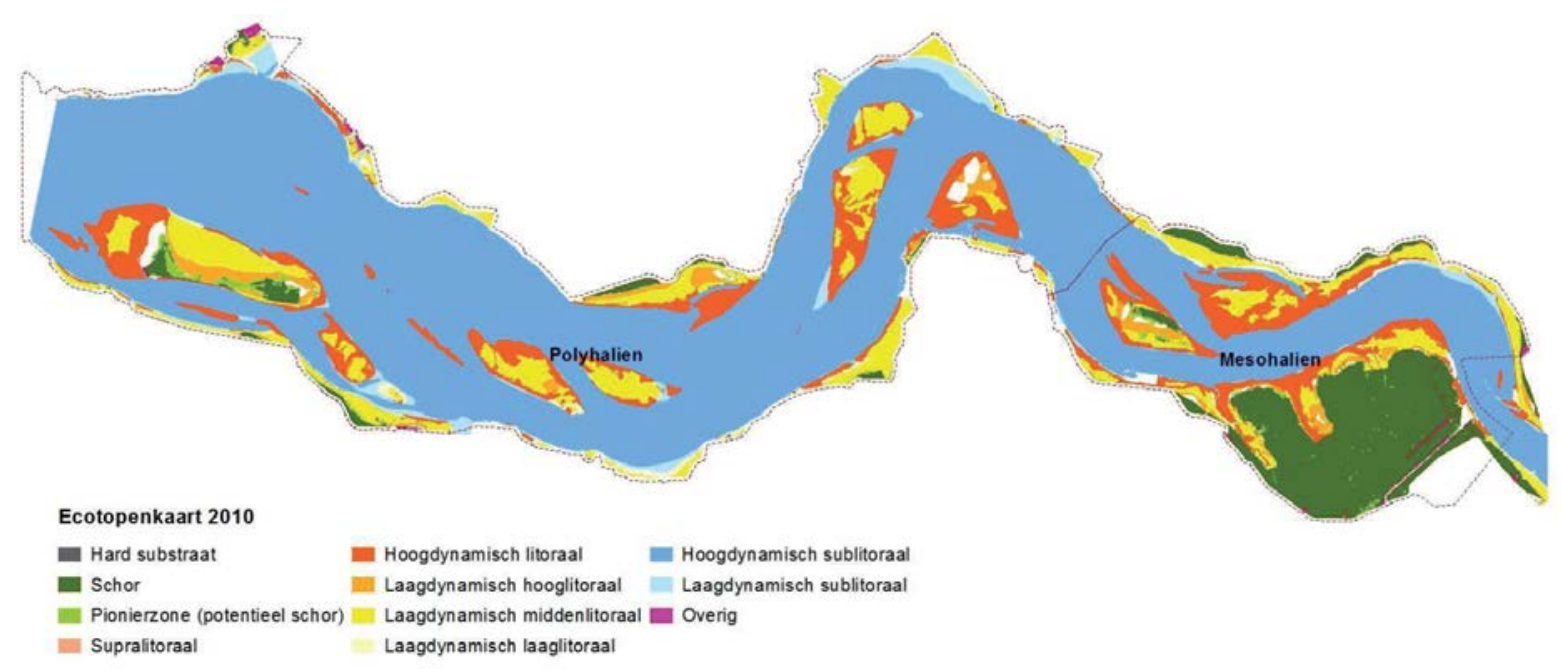

Figuur 3.2. Ecotopenkaart van de Westerschelde (Van den Heuvel-Greve et al., 2016).

Stekelroggen gebruiken habitats met een brede range aan sedimenttypes (slib, fijn zand, grof zand, gravel, kiezel). De juvenielen gebruiken met name slib en zandige sedimenten, die het gehele westerschelde areaal beslaan, en de adulte stekelroggen gebruiken ook grind en kiezels, welke afwezig tot zeer schaars zijn in de Westerschelde.

\subsection{Bodemschuifspanning}

Bodemschuifspanning is door Martin et al. (2012) genoemd als een belangrijke voorspeller voor het voorkomen van stekelrog. Bodemschuifspanning is een maat voor de lokale bodemdynamiek als gevolg van zowel waterstroming als golfwerking. In de Westerschelde is de bodemschuifspanning het grootste in de diepe stromingsgeulen in het midden en westelijke deel Westerschelde (Figuur 3.3). 


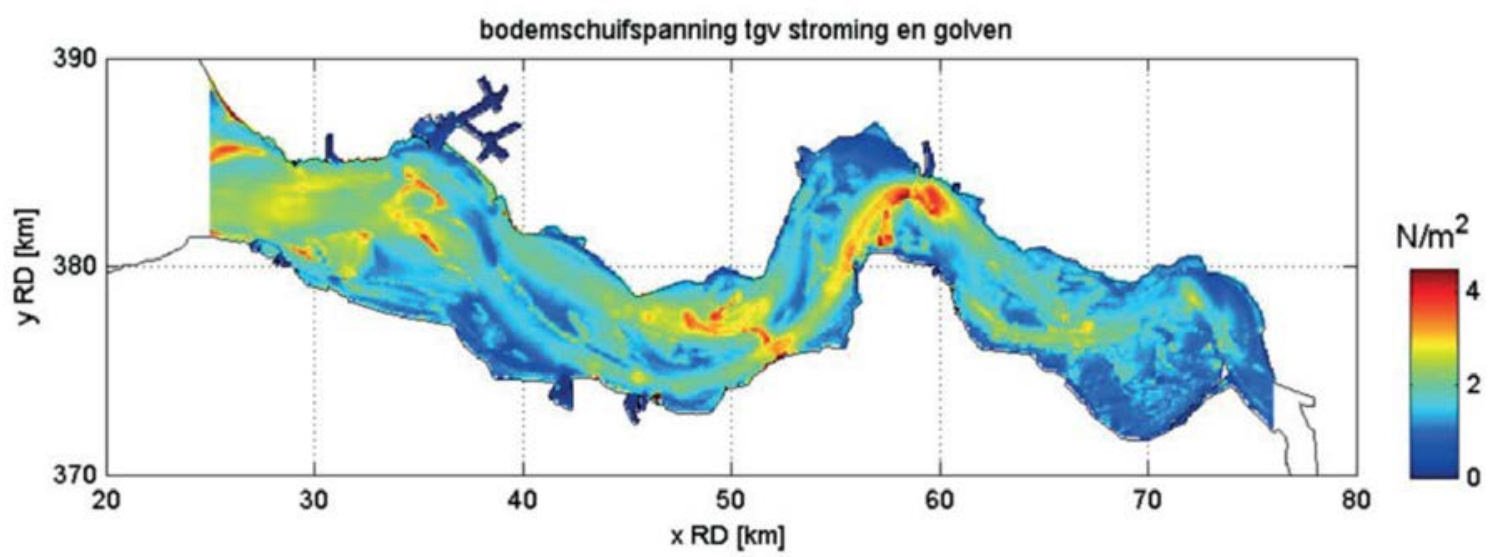

Figuur 3.3. Bodemschuifspanning van de Westerschelde (Poortman, 2013).

Maxwell et al. (2009) vond een preferentie van stekelroggen voor een bodemschuifspanning van $<1.5$ $\mathrm{N} / \mathrm{m}^{2}$, welke ruimschoots aanwezig is in de Westerschelde. Martin et al. (2012) vond dat met name de juvenielen habitats met zwakkere bodemschuifspanning prefereerden en adulten intermediaire tot sterkere getijdenstromingen. Beide typen habitats zijn in de Westerschelde aanwezig: In Figuur 3.3 is zwakkere bodemschuifspanning $\left(<1,5 \mathrm{~N} / \mathrm{m}^{2}\right)$ aangegeven met blauw en intermediaire/sterkere $(2-4$ $\mathrm{N} / \mathrm{m}^{2}$ ) met groen, geel en rood.

\subsection{Watertemperatur}

De watertemperatuur in de Westerschelde (bij Vlissingen) varieert van minimaal 0 tot $8{ }^{\circ} \mathrm{C}$ in de winter tot maximaal $18-23^{\circ} \mathrm{C}$ in de zomer. Dit verschilt van jaar tot jaar (Figuur 3.4 en 3.5).

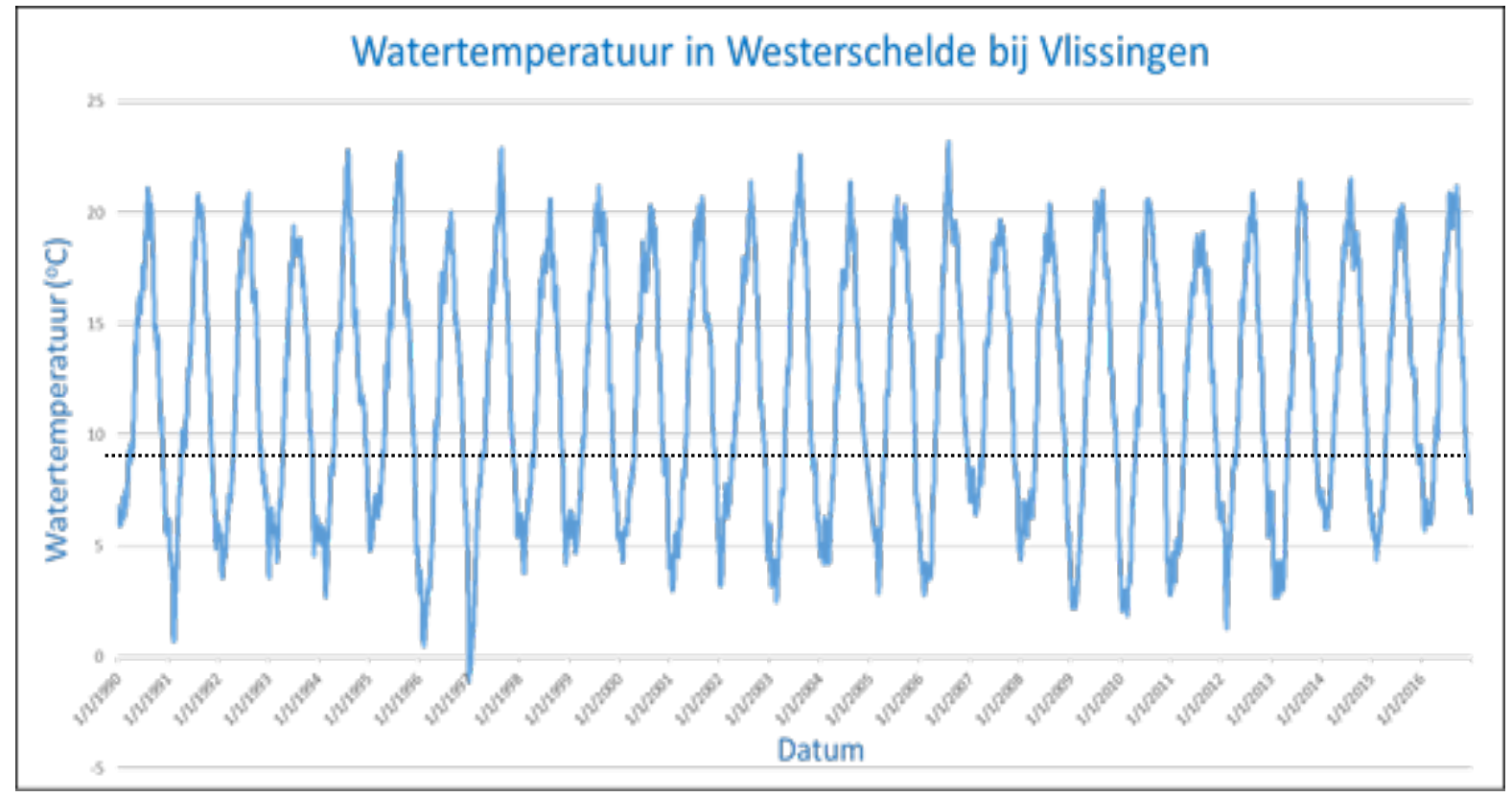

Figuur 3.4. De watertemperatuur in de Westerschelde bij Vlissingen van 1990-2016 (RWS waterbase), met daarin aangegeven de temperatuurondergrens van stekelroggen in het Kanaal (Martin et al. 2012).

Martin et al. (2012) laat zien dat stekelroggen in het Kanaal de hogere temperaturen prefereren in de daar voorkomende range $9.5-19^{\circ} \mathrm{C}$, waarbij de juvenielen hogere temperaturen prefereren dan de adulten. Dit zou betekenen dat de watertemperaturen in het winterhalfjaar van november tot april te laag zouden zijn voor adulte en met name ook voor juveniele stekelroggen. In het zomerhalfjaar (meioktober) zijn de watertemperaturen zeker geschikt voor stekelroggen. Dit betekent dat stekelroggen die in het zomerhalfjaar de Westerschelde benutten dan vervolgens waarschijnlijk in de winter naar iets 
warmere wateren gaan en pas in het voorjaar weer naar de Westerschelde zouden kunnen terugkeren. Dergelijke migraties laten stekelroggen langs de Engelse kust ook zien bleek uit studies met gemerkte stekelroggen (Walker et al., 1997; Hunter et al., 2005).

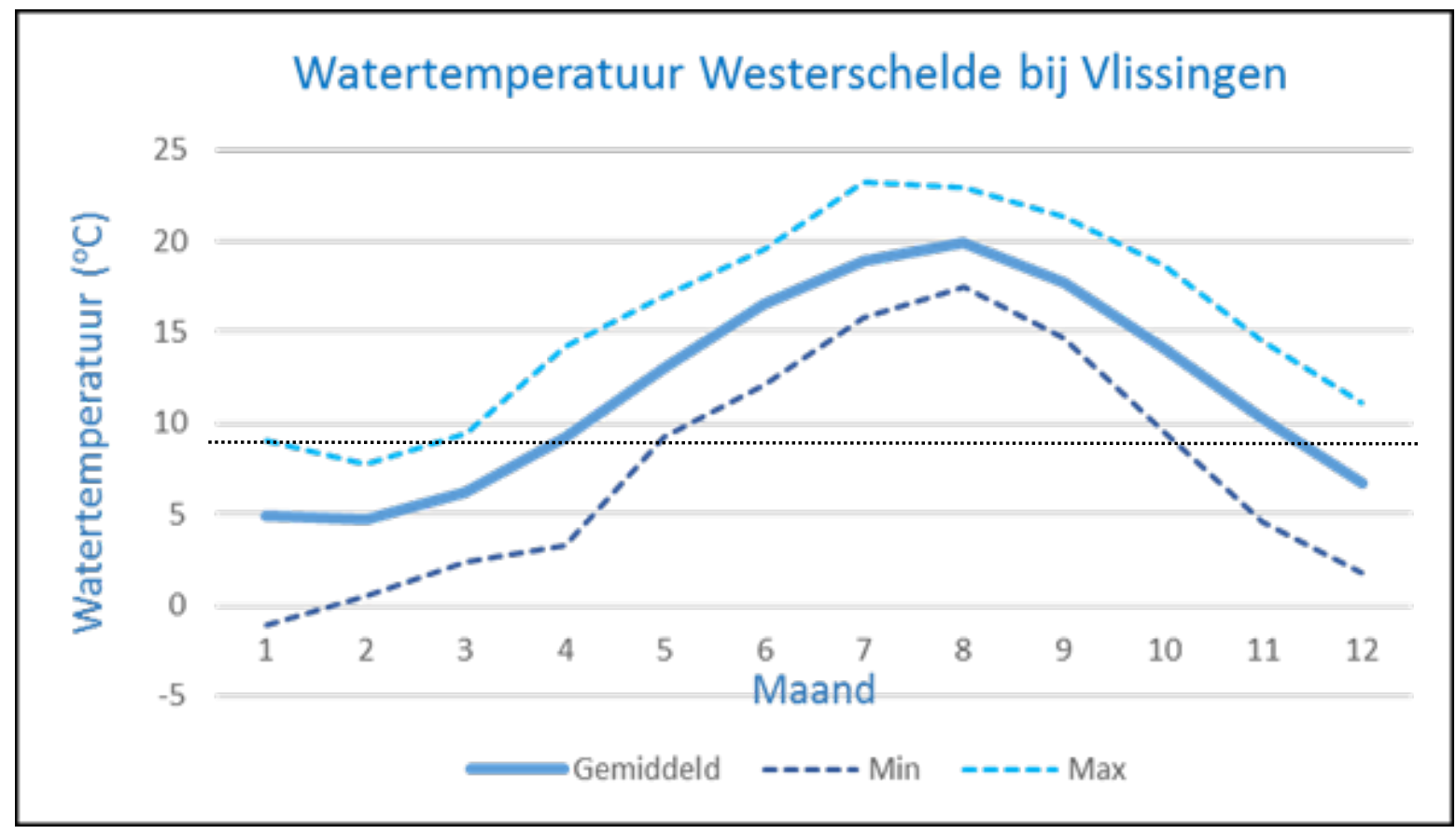

Figuur 3.5. De gemiddelde, minimum en maximum watertemperatuur per maand in de Westerschelde bij Vlissingen over de periode van 1990-2016 (RWS waterbase), met daarin aangegeven de ondergrens van watertemperatuur van stekelroggen in het Kanaal (Martin et al. 2012).

\subsection{Zoutgehalte}

De Westerschelde is een open en dynamisch estuarium en kent derhalve een sterke zoet-zout gradiënt die varieert al naar gelang het getijde en de rivierafvoer van de Schelde (zie Figuur 3.6 voor voorbeeld van zoet-zout gradiënt). De zoet-zout dynamiek in de Schelde en Westerschelde gedurende 1996-2002 is weergegeven in Figuur 3.7. De sterkste gradiënt en wisselingen in zoutgehalten zijn te vinden bij de Nederlands-Belgische grens.

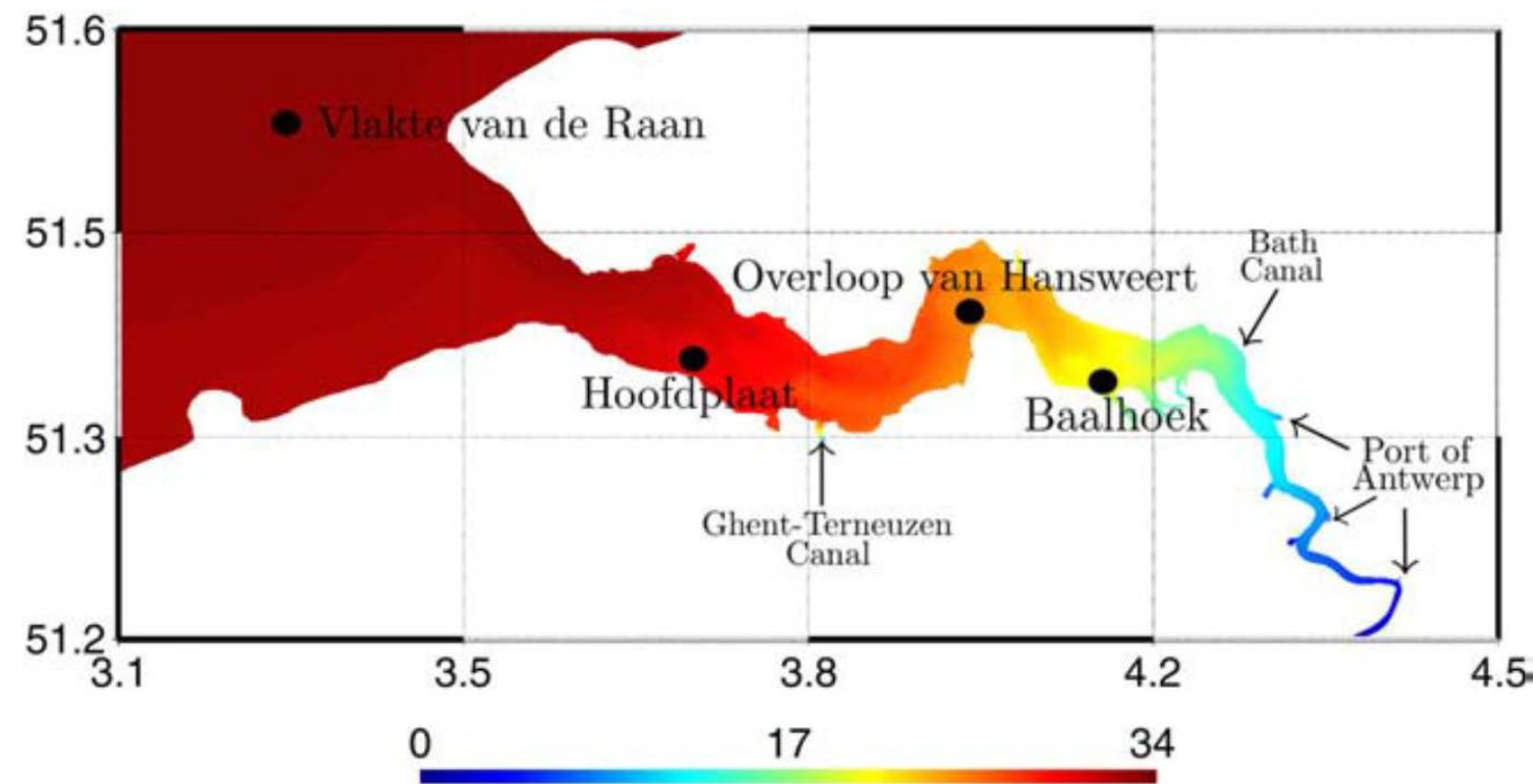

Figuur 3.6. Zoet-zout gradiënt in de Westerschelde op 2008/09/01 om 00:00 (de Brye et al., 2010). 


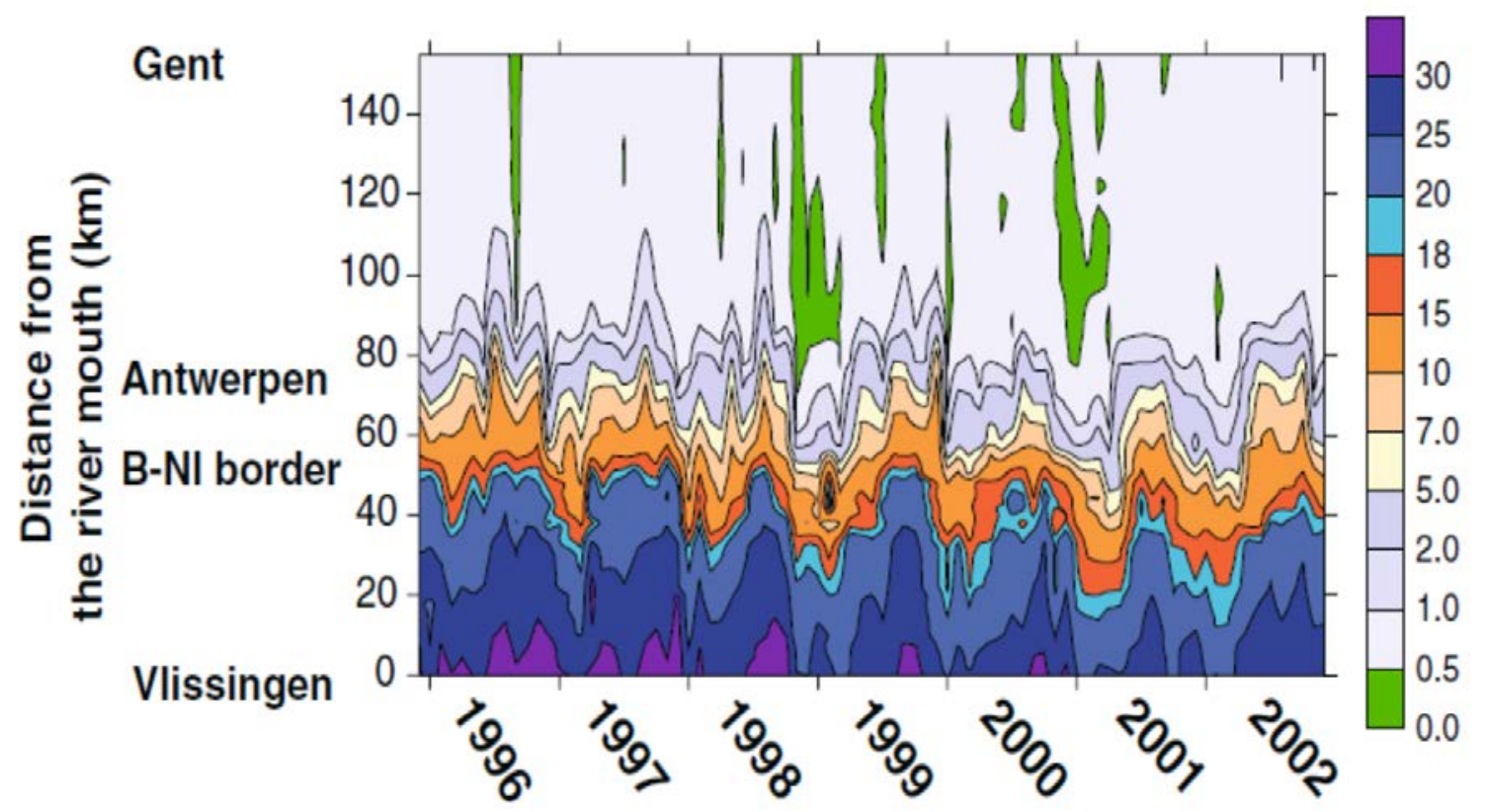

Figuur 3.7. Dynamiek in zoutgehalten in de Westerschelde bij Vlissingen tot aan de Schelde bij Gent tijdens de periode 1996-2002 (van Damme et al., 2005).

In de publicaties over de gebieden waar stekelroggen zijn aangetroffen (I erse Zee, Engels Kanaal, en centrale Middellandse Zee) zijn wel de ranges van de daar heersende zoutgehalte gemeten: 32,4 - 34,9 ppm (English Channel); 32,6 - 35,2 ppm (I rish Sea); 37,9 - 38,3 ppm (c. Mediterrean Sea). Daarnaast zijn er aanwijzingen dat de stekelrog en met name de juvenielen ook habitats met lagere zoutgehalten benutten (Martin et al., 2012), maar hier is niet aangegeven bij welke saliniteit deze nog zijn aangetroffen. Ellis et al. (2008) geeft aan dat de dichtheden van stekelrog in de zuidelijke Noordzee met name in enkele mondingen van estuaria erg hoog zijn, zoals het Theems estuarium (Figuur 3.8).

Er zijn in merk-terugvangst studies met stekelrog in de zuidelijke Noordzee ook terugvangsten tot in het Thames estuarium gedaan. Het is onbekend bij welke zoutgehalten deze nog waargenomen zijn Figuur 3.9).

Wat zoutgehalten betreft is voor (sub)adulte stekelroggen met name het westelijke deel van de Westerschelde tot aan $10 \mathrm{~km}$ ten oosten van Vlissingen geschikt en wellicht tot voorbij Terneuzen en wellicht Hansweert. Juveniele stekelroggen kunnen zeer waarschijnlijk habitats dieper in de Westerschelde benutten, maar hoe ver oostelijk is momenteel onbekend en eveneens welke zoutgehalten ze hierbij prefereren. 


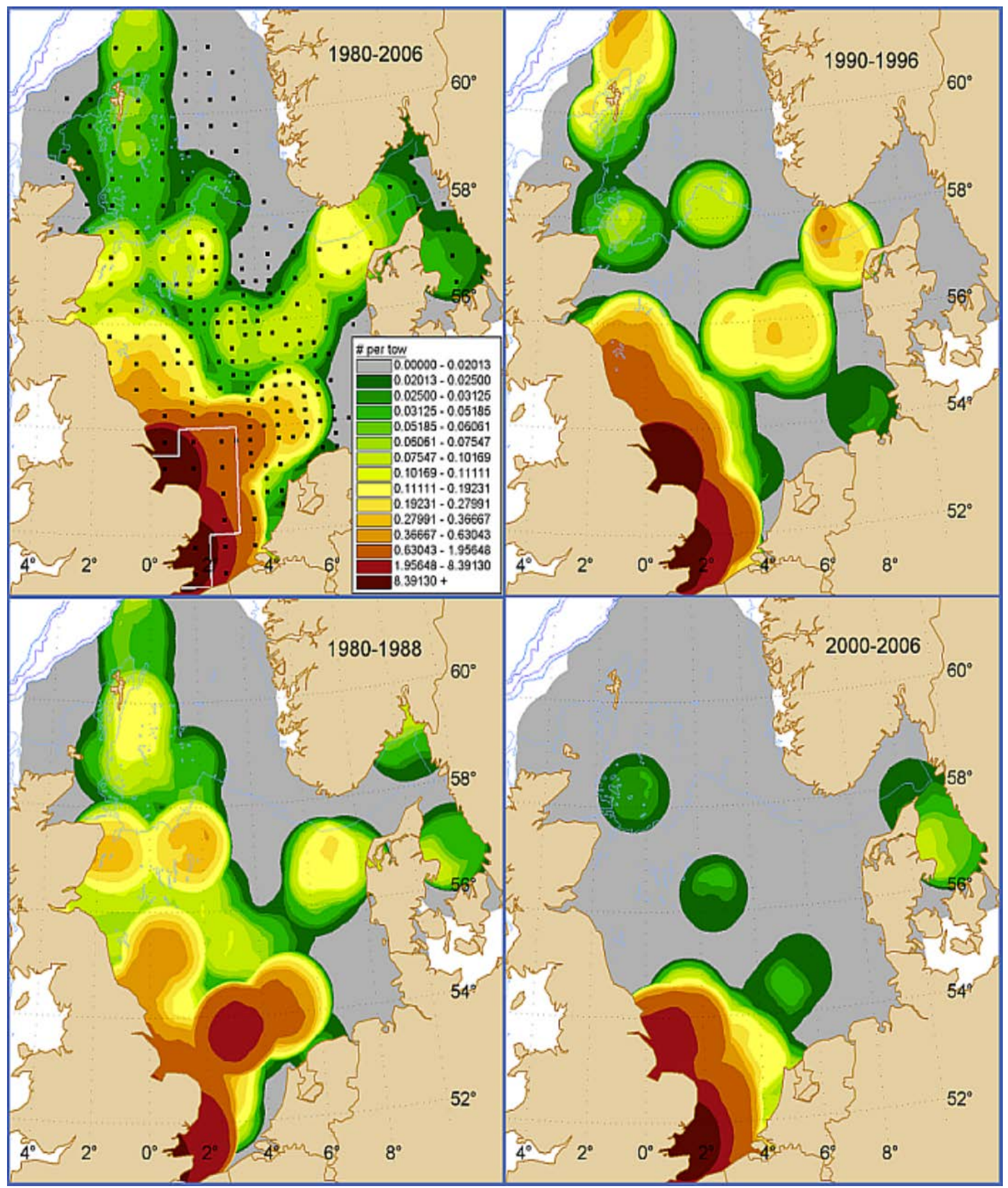

Figuur 3.8. Verspreiding van stekelrog Raja clavata in de Noordzee gedurende vier periodes en gemiddeld over de gehele periode (1980-2006), zoals gerapporteerd tijdens de Q1 IBTS survey. Dichtheidsklassen zijn uitgedrukt in aantallen per trek. Rood en bruin geven hoge dichtheden weer, geel en groen zijn lage dichtheden, bij grijs ontbreekt de stekelrog in de surveys (uit: Ellis et al., 2008). 


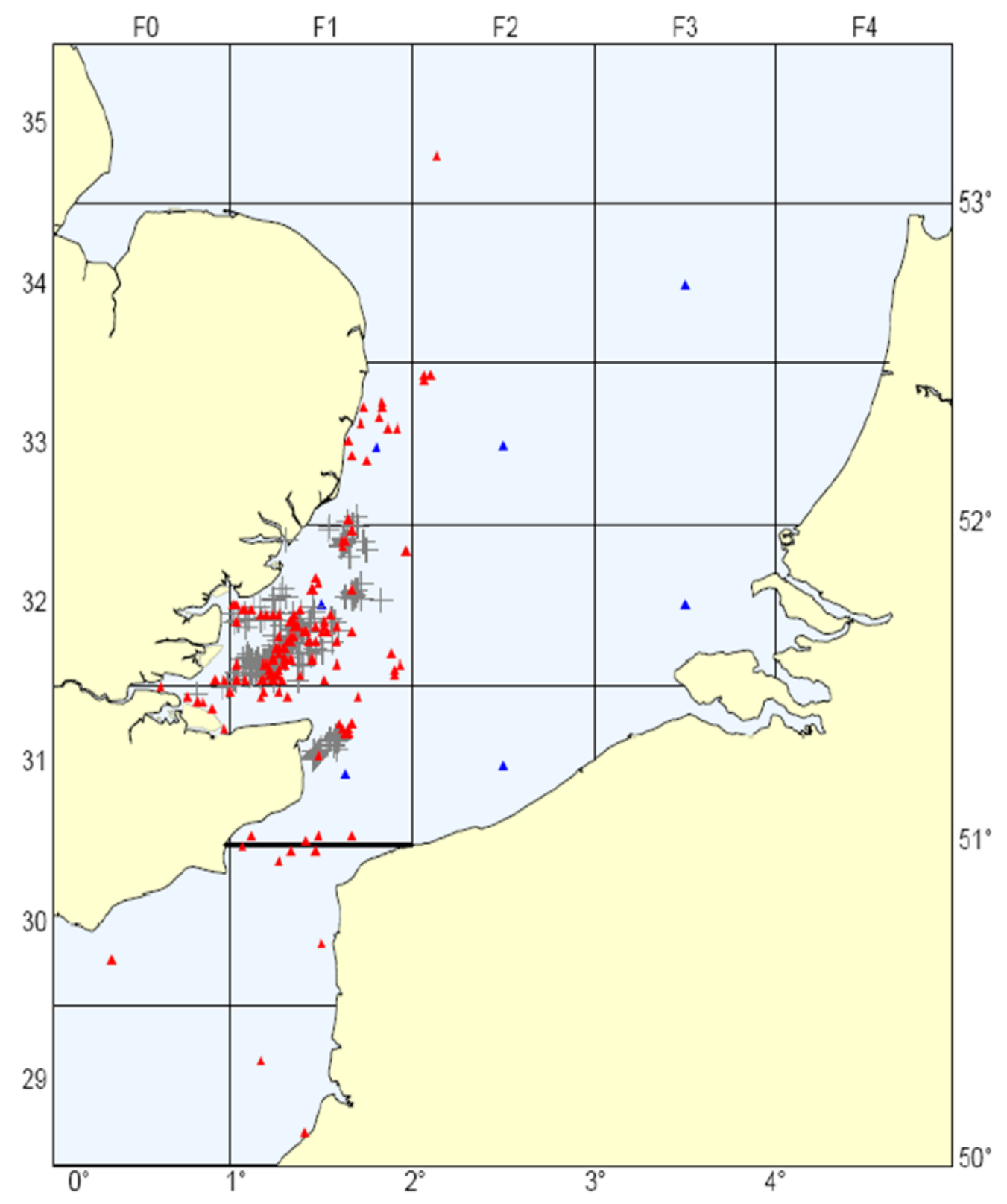

Figuur 3.9. Resultaten van merk-terugvangst studies van stekelrog in $2007 / 2008$. Grijze kruizen zijn de vangst- en terugzetlocaties. Rode driehoeken geven de locaties met terugvangsten met nauwkeurige positie en blauwe posities zijn terugvangsten met onnauwkeurige positie (op ICES kwadrant niveau), (uit: Ellis et al., 2008).

\subsection{Ontwikkelingen in waterkwaliteit}

De Schelde kende in de vorige eeuw een slechte waterkwaliteit, waarbij de zuurstofgehalten in het Belgische deel in sommige jaren langdurig tegen hypoxia (tekort aan zuurstof) aanzaten. In de $21^{\text {ste }}$ eeuw is de waterkwaliteit sterk verbetert en komt ernstig zuurstoftekort $(<2.5 \mathrm{mg} / \mathrm{l})$ in het Belgische deel niet meer voor (Figuur 3.10). 


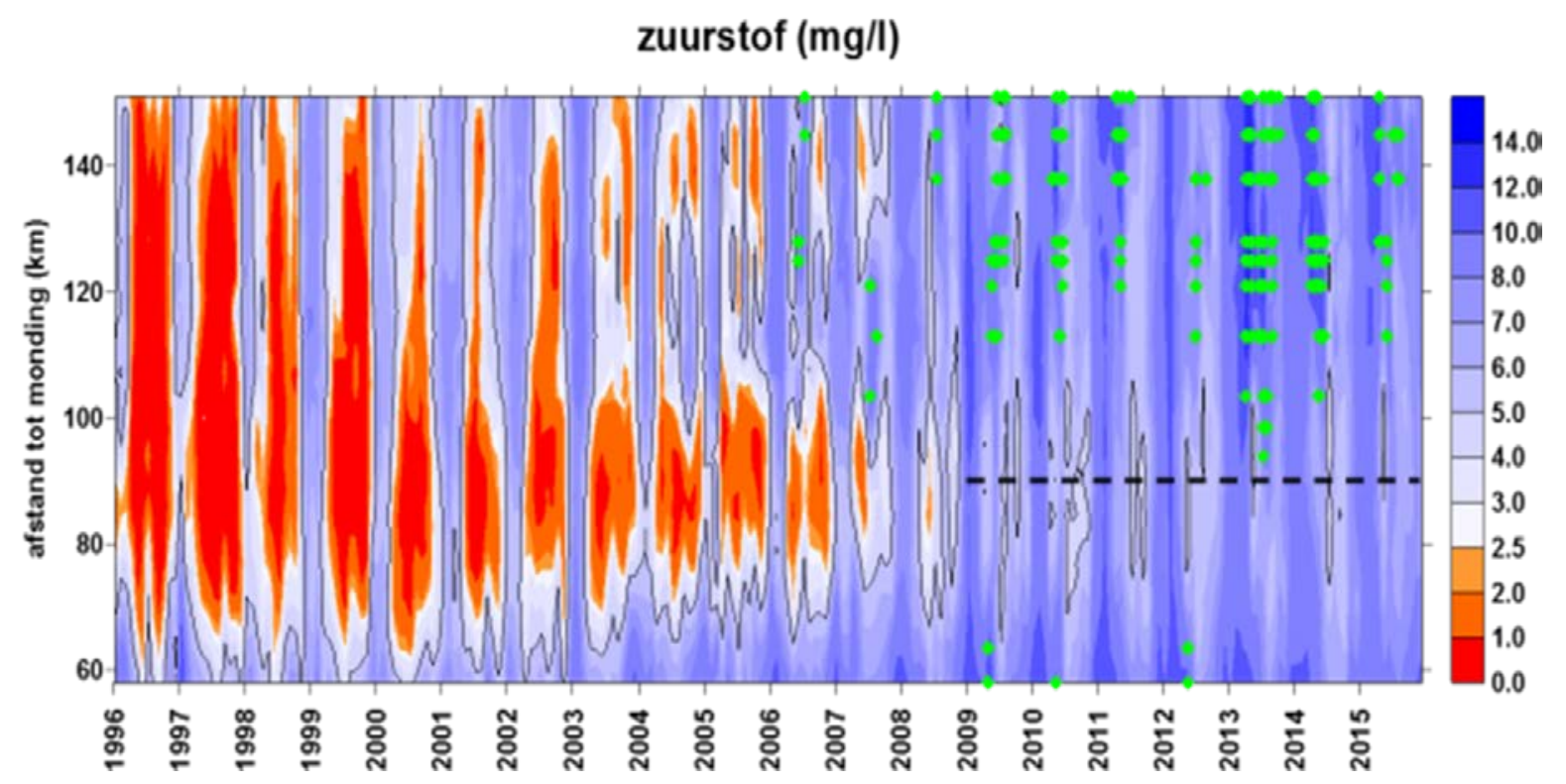

Figuur 3.10. Dynamiek in zuurstofgehalten in de Schelde en Westerschelde gedurende 1996-2016 Ernstig zuurstoftekort: $<2,5 \mathrm{mg} / \mathrm{l}$ (oranje en rood). Zwarte contouren rondom kleuren: $5 \mathrm{mg} / \mathrm{l}$. Groene stippen: metingen met oversaturatie (teveel zuurstof door sterke algenbloei) (bron: http://www.omesmonitoring. be/en/node/33).

Een uitvoerige beschouwing van de waterkwaliteit ligt buiten de scope van deze rapportage, maar het is aannemelijk dat de zuurstofhuishouding in de Westerschelde geen problemen meer zal opleveren voor de stekelrog.

\subsection{Biotische factoren (voedselbeschikbaarheid)}

Biotische factoren maken uiteraard een belangrijk deel uit van de habitatvoorkeur van de stekelrog. Echter, hierover is weinig bekend (J ongbloed et al. 2017). In voorliggende rapportage worden kort twee ontwikkelingen in potentieel voedselaanbod in de Westerschelde aangestipt: de abundantie van garnalen (Figuur 3.11) en ontwikkelingen in de bodemfauna van de Westerschelde gedurende 1992-2014 (Figuur 3.12). Deze laten zien dat het aanbod van garnalen vergelijkbaar is met de Oosterschelde en Voordelta en gemiddeld iets hoger lijkt dan voor de Hollandse kust.

Ontwikkelingen in de bodemfauna van de Westerschelde laten zien dat populaties van bodemdieren de afgelopen jaren zijn toegenomen, met meer dan 50 procent sinds 1992, zo blijkt uit analyses van RWS data door het CBS. Dit cijfer is gebaseerd op 35 diersoorten (Figuur 3.12). Deze toename wordt met name aan de verbetering van de kwaliteit van het water en bodem in de Schelde en Westerschelde toegeschreven.

In hoeverre de biotische factoren in de Westerschelde geschikt zijn voor de stekelrog is met de huidige kennis niet te bepalen. De ontwikkelingen in potentiële voedselorganismen, zoals kleine kreeftachtigen die een belangrijk voedsel voor juveniele stekelroggen vormen, als de bodemfauna in zijn geheel, zijn echter positief. 


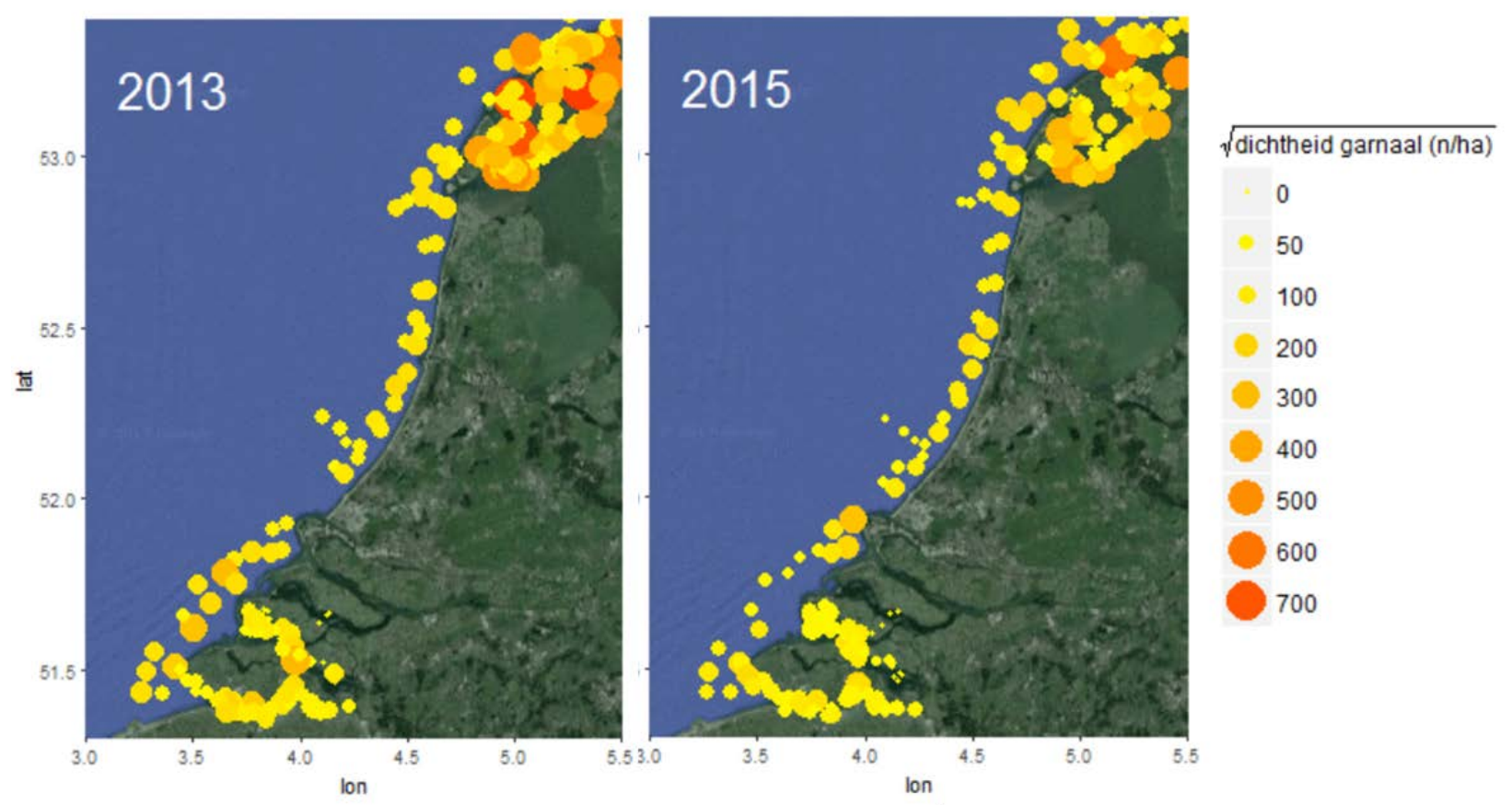

Figuur 3.11. Dichtheden van de gewone garnaal langs de Nederlandse kust (bron: WMR database, uit Jongbloed et al. 2017).

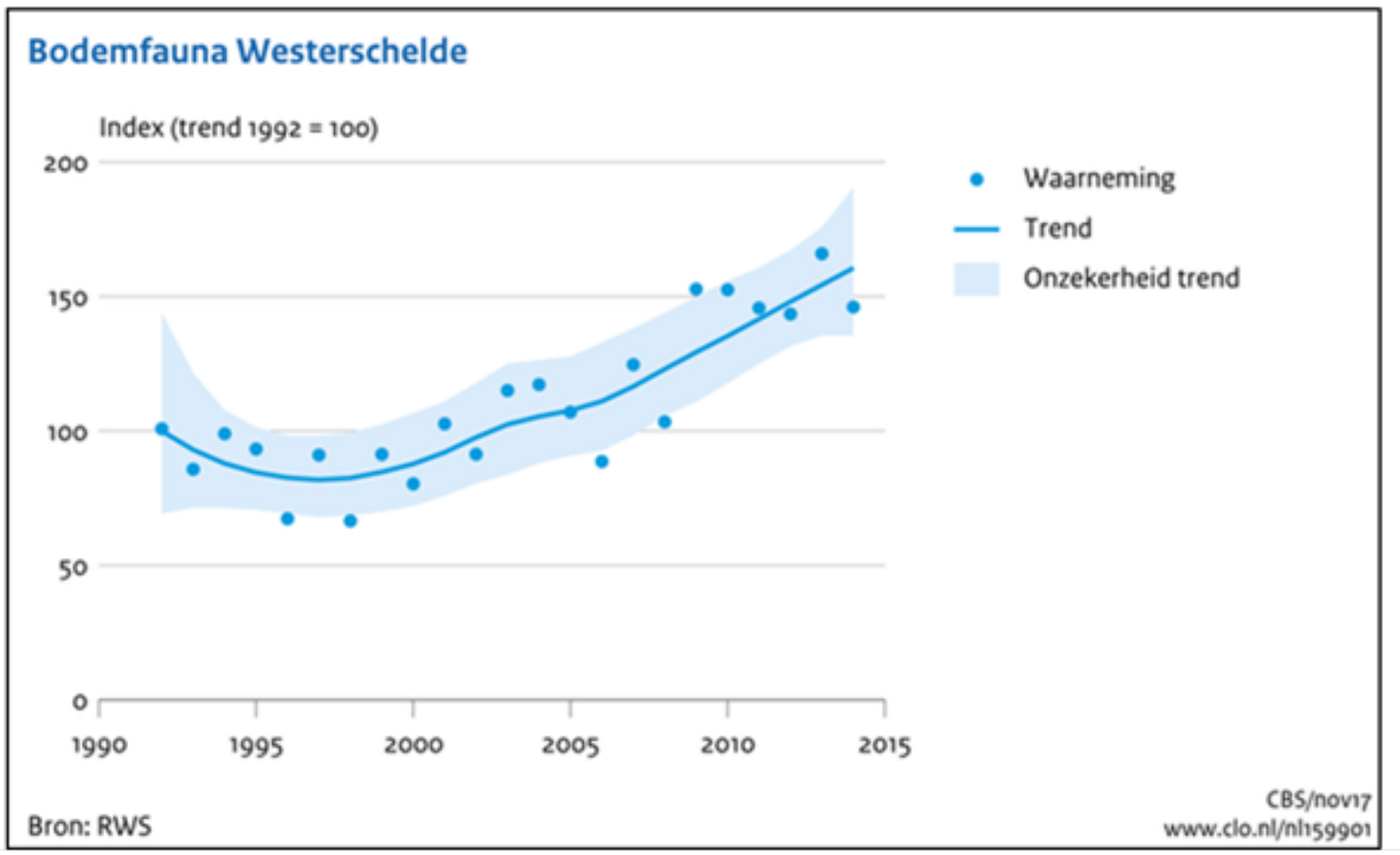

Figuur 3.12. Ontwikkelingen in de bodemfauna, gebaseerd op 35 diersoorten, gedurende 1996-2014 (bron data: RWS). 


\subsection{Inschatting habitatgeschiktheid van de Westerschelde voor stekelrog}

Bovenstaande beschouwing van de potentiële geschiktheid van de Westerschelde als habitat voor de stekelrog is samengevat in tabel 3.1.

Tabel 3.1 Waarden van milieufactoren in de Westerschelde en een eerste inschatting van de geschiktheid daarvan voor de stekelrog, onderverdeeld in juvenielen en (sub)adulten.

\begin{tabular}{|c|c|c|c|}
\hline Factoren & Waarden & $\begin{array}{l}\text { Geschiktheid van } \\
\text { gebied voor } \\
\text { juvenielen } \\
\text { (0-1 groep) }\end{array}$ & $\begin{array}{l}\text { Geschiktheid van } \\
\text { gebied voor } \\
\text { (sub)adulten }(2+ \\
\text { groep) }\end{array}$ \\
\hline Diepte & $\begin{array}{l}\text { Diepte } 0 \text { - } 51 \mathrm{~m} \text {, met grote } \\
\text { variatie over de verschillende } \\
\text { diepteklassen. }\end{array}$ & Geschikt & Geschikt \\
\hline $\begin{array}{l}\text { Bodemschuif-spanning } \\
\text { (stroming en golven) }\end{array}$ & $\begin{array}{l}\text { Range: } 0-5 \mathrm{~N} / \mathrm{m}^{2} \text {, zeer } \\
\text { variabel binnen het gebied, } \\
\text { met de grootste waarden in } \\
\text { de diepe geulen rond } \\
\text { Vlissingen en Terneuzen en } \\
\text { Hansweert. }\end{array}$ & $\begin{array}{l}\text { Rondom Vlissingen deels } \\
\text { minder geschikt. Tussen } \\
\text { Vlissingen en Terneuzen } \\
\text { goed geschikt. Rondom } \\
\text { Hansweert deels geschikt, } \\
\text { m.n. de ondiepere delen. }\end{array}$ & Geschikt \\
\hline Zoutgehalte & $\begin{array}{l}\text { Range: } 0 \text { - } 35 \text { ppt. Sterke } \\
\text { gradiënt van zoet naar zout } \\
\text { die wisselt met getijde en } \\
\text { vooral rivierafvoer in de } \\
\text { Schelde. Rondom Vlissingen } \\
\text { meestal > } 30 \text { ppt. Bij } \\
\text { Terneuzen meestal > 20-25, } \\
\text { Rondom Hansweert meestal } \\
>18 \text { ppt. }\end{array}$ & $\begin{array}{l}\text { Het gebied ten westen van } \\
\text { Terneuzen zal geschikt zijn. } \\
\text { In hoeverre juveniele } \\
\text { stekelroggen ook dieper het } \\
\text { estuarium zullen gebruiken } \\
\text { is onbekend. }\end{array}$ & $\begin{array}{l}\text { Groot deel van de } \\
\text { Westerschelde kent relatief } \\
\text { lage zoutgehalten. Met name } \\
\text { tde monding en het gebied } \\
\text { van grofweg } 10 \mathrm{~km} \text { rondom } \\
\text { Vlissingen is geschikt, } \\
\text { wellicht nog verder } \\
\text { oostwaarts, maar hier is } \\
\text { momenteel geen kennis over } \\
\text { beschikbaar. }\end{array}$ \\
\hline Watertemperatuur & Tussen 0 en $23^{\circ} \mathrm{C}$. & $\begin{array}{l}\text { Geschiktheid is sterk } \\
\text { afhankelijk van de tijd van } \\
\text { het jaar. Geschikt van mei- } \\
\text { november en ongeschikt } \\
\text { van december - april. }\end{array}$ & $\begin{array}{l}\text { Geschiktheid is sterk } \\
\text { afhankelijk van de tijd van } \\
\text { het jaar. Geschikt van mei- } \\
\text { november. en minder } \\
\text { geschikt van december-april. }\end{array}$ \\
\hline Sediment type & $\begin{array}{l}\text { Variërend van grof tot fijn } \\
\text { zand in de stroomgeulen tot } \\
\text { slibrijker rondom de platen. }\end{array}$ & Geschikt & Waarschijnlijk geschikt \\
\hline
\end{tabular}

\subsection{Inschatting van de migratie vanuit en bereikbaarheid van Westerschelde}

De Westerschelde is een open estuarium met een (voor Nederlandse begrippen) nog natuurlijke dynamiek in getijdenbewegingen en stromingen. Stekelroggen kunnen vrij de Westerschelde in en uit migreren. Ook de aanwezigheid van veel scheepvaart lijkt geen ernstige beperking te zijn aangezien de stekelrog ook gebruik maakt van de monding van het druk bevaren Theems estuarium. Uit merkterugvangst experimenten zijn gemerkte stekelroggen uit het 'Greater Thames Estuary' ook opgedoken voor de Belgische en Nederlandse kust (zie Figuur 3.9, Ellis et al. 2008). Dit maakt het zeer aannemelijk dat de stekelroggen vanuit de Westerschelde ook naar geschikte overwinterings- of paaigebieden kunnen trekken en hierin geen belemmeringen kennen. 


\section{$4 \quad$ Conclusies en aanbevelingen}

Voor een uitgebreide discussie van de kennis, en het gebrek daaraan, van de habitateisen van de stekelrog wordt verwezen naar Jongbloed et al. (2017). In dit hoofdstuk worden specifiek de belangrijkste conclusies en aanbevelingen voor de habitatgeschiktheid van de Westerschelde gegeven.

\subsection{Conclusies}

Op basis van de beschikbare literatuur en van correlaties die reeds zijn vastgesteld in andere gebieden in of nabij de Noordzee, waar stekelroggen relatief veel voorkomen (o.a. Theems estuarium, het Kanaal, I erse Zee) kunnen voor de Westerschelde de volgende conclusies getrokken worden:

- Voor juveniele stekelrog lijkt het westelijke deel van de Westerschelde (grofweg ten westen van Terneuzen) wat betreft waterdiepte, sedimenttype en zoutgehalte geschikt. Voor bodemschuifspanning lijkt binnen dit westelijke deel vooral het gebied tussen Vlissingen en Terneuzen het meest geschikt. In hoeverre juveniele stekelrog de Westerschelde nog verder oostelijk van Terneuzen zou kunnen benutten is onbekend, al zijn er wel aanwijzingen in de Theems dat deze ook dieper het estuarium kan inzwemmen. Wat watertemperatuur betreft zijn de waarden in de winter te laag en zullen de stekelroggen waarschijnlijk seizoenmigratie naar nabij gelegen overwinteringsgebieden moeten ondernemen.

- Voor (sub)adulte stekelroggen is het spectrum aan waterdieptes dat aanwezig is en de bodemschuifspanningen die optreden geschikt. De zoutgehalten rondom Vlissingen zijn geschikt voor (sub)adulte stekelroggen, maar het is de vraag of deze nog lagere zoutgehalten zullen willen benutten ten oosten hiervan. (Sub)adulte stekelroggen kunnen een breed spectrum van sedimenttypen benutten. In hoeverre het ontbreken van grof substraat als gravel en kiezels in de Westerschelde als beperkend zal gelden is niet bekend. De watertemperatuur zal in de winter te laag zijn en derhalve zullen ook (sub)adulte stekelroggen seizoenmigratie ondernemen aar overwinteringsgebieden in bijvoorbeeld het Theems kustgebied of het Kanaal. Er zijn geen migratiebelemmeringen op de routes naar deze gebieden.

- De connectiviteit van de Westerschelde met andere opgroei- en overwinteringsgebieden in de zuidelijke Noordzee en Engelse kanaal is zonder barrières. Stekelroggen kunnen vrij bewegen tussen deze verschillende habitats.

Over de biotische factoren die bepalen of habitats geschikt zijn is veel minder bekend. Dat geldt ook over de eisen die stekelroggen aan hun eileg-gebieden stellen. Het aanbod aan garnalen, een belangrijke voedselbron voor juveniele stekelroggen, lijkt goed. De ontwikkeling in waterkwaliteit en bodemfauna in de Westerschelde is gunstig. Het is uiteraard mogelijk, zelfs waarschijnlijk, dat er nog andere factoren zijn die de geschiktheid van een habitat bepalen. Bijvoorbeeld m.b.t. structuren op de bodem voor het afzetten van eikapsels.

Menselijke activiteiten op de stekelroggen vallen buiten de scope van deze rapportage. Uit de literatuur wordt wel duidelijk, en de experts wijzen daar ook op, dat intensieve boomkorvisserij en garnalenvisserij stekelrogpopulaties hebben gereduceerd en de opbouw van populaties in de weg kunnen staan (Jongbloed et al. 2017). 


\subsection{Aanbevelingen en overwegingen}

Over onderzoek naar de geschiktheid van habitat voor stekelroggen en voor het bepalen of en waar er in de Westerschelde juveniele stekelroggen uitgezet kunnen worden zouden wij de volgende aanbevelingen en overwegingen willen geven:

- Meer basisonderzoek naar de biologie van stekelroggen. Hier kan beheer en beleid dan op worden gestoeld. Hierbij kan gedacht worden aan onderzoek naar de invloed van een biotische factoren zoals predatie (op eikapsels en juveniele stekelroggen), parasieten en ziekten. En onderzoek naar de habitateisen voor het aanhechten van eikapsels en zeer jonge stekelroggen en of deze in de Westerschelde aanwezig zijn. Als er meer kennis is over de biologie en het voorkomen van stekelrog is kan er ook een kwantitatieve habitatgeschiktheidsanalyse met modellen worden uitgevoerd om de (relatieve) habitatgeschiktheid van de stekelrog in de Westerschelde te analyseren. Hiervoor is echter nog veel onderzoek en data nodig en dit zal niet op korte termijn beschikbaar zijn.

- $\quad$ Er zijn nog veel onzekerheden in zowel de habitatgeschiktheid van de Westerschelde als ook in de biologie en het gedrag van stekelroggen. Het is daarom aan te bevelen hierover middels goede monitoring en onderzoek rondom pilot uitzettingen kennis op te doen en op basis hiervan verdere uitzettingen te evalueren. Het merken van alle uit te zetten individuen met externe merken is belangrijk om de verspreiding en het lot van individuen te kunnen volgen (merkterugvangst onderzoek). Een aantal individuen kan met elektronische zendertechnieken worden gevolgd in hun gedrag en migraties. De Westerschelde is hiervoor zeer geschikt omdat hier al een dicht netwerk aan VEMCO akoestische detectiestations aanwezig is, opgezet voor onderzoek aan andere vissoorten (zie Figuur 4.1). VEMCO-zenders en -data storage tags (DST) kunnen veel gegevens opleveren over de verblijftijd van stekelroggen in de verschillende delen van de Westerschelde (deze is door een aantal dekkende raaien goed te bepalen). Ook kan er zo duidelijkheid worden gekregen of stekelroggen ook habitats met lagere zoutgehalten benutten.

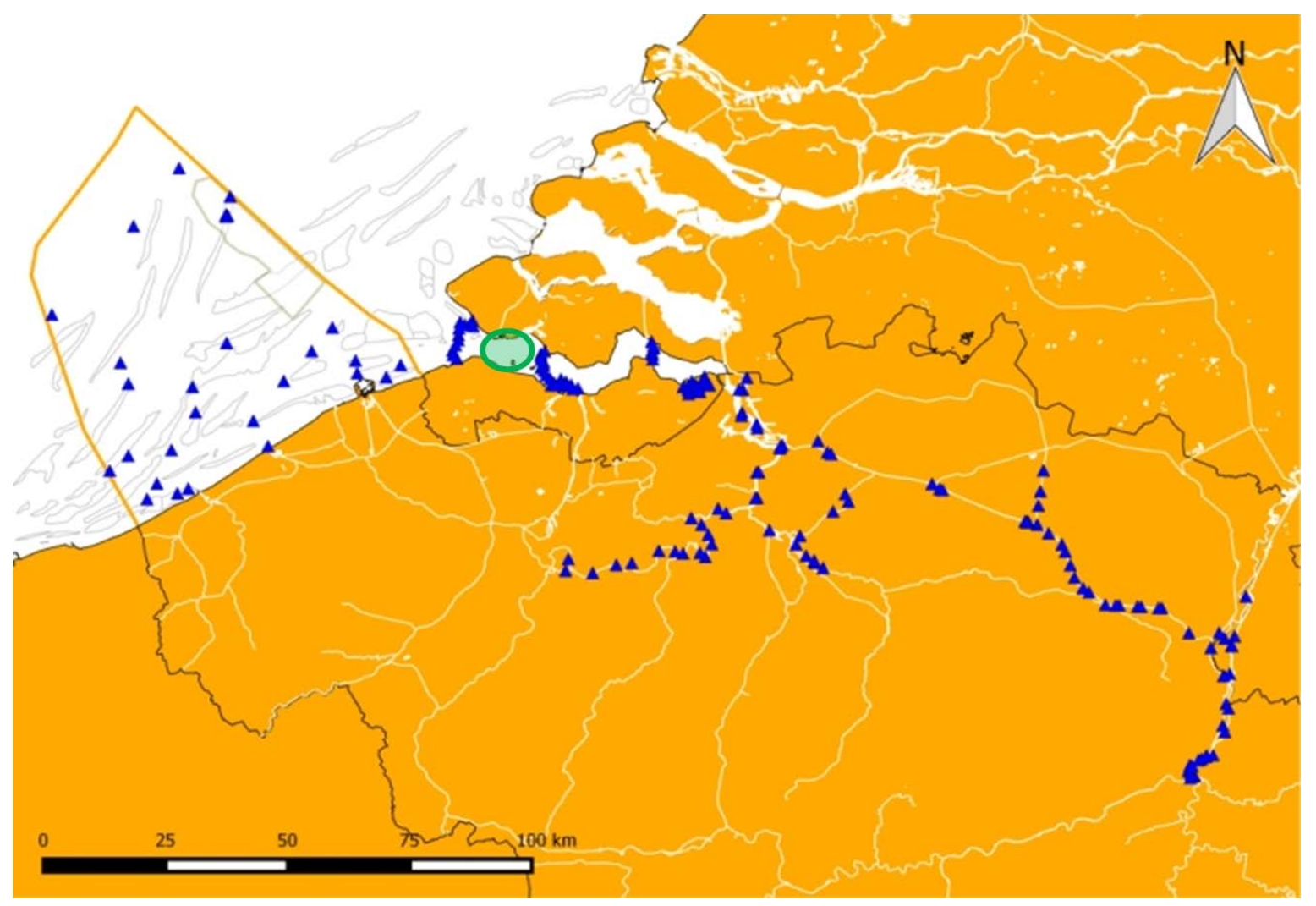

Figuur 4.1. Overzichtskaart van het netwerk aan VEMCO-detectiestations in het stroomgebied van de Schelde, Westerschelde en de Belgisch-Nederlandse kust (bron: http://www.lifewatch.be/en/fishacoustic-receiver-network). De groene locatie lijkt de meest geschikte plaats om juveniele stekelroggen uit te zetten, mocht hiertoe besloten worden. 
- Gezien de grotere onzekerheid van de geschiktheid van de Westerschelde voor (sub)adulte stekelroggen is het niet aan te bevelen deze zonder verdere kennisontwikkeling op dit moment in de Westerschelde oostelijk van Vlissingen uit te zetten. Indien er juveniele stekelroggen worden uitgezet in de Westerschelde dan lijkt het gebied tussen Vlissingen en Terneuzen hiervoor het meest geschikt omdat hier de zoutgehalten hoog genoeg zijn en de bodemschuifspanning het meest geschikt is. Dergelijk onderzoek zou laat in het voorjaar kunnen starten, zodra de watertemperaturen ruim boven $9{ }^{\circ} \mathrm{C}$ liggen en nog een heel groeiseizoen met hogere temperaturen in het verschiet ligt. Bijkomend voordeel is dat deze locatie tussen twee dekkende raaien van VEMCO ontvangers ligt en dat gezenderde juveniele stekelroggen dan zeer goed kunnen worden gevolgd in hoelang ze in de westelijke Westerschelde verblijven, of ze ook de oostelijker gelegen zoet-zout gradiënten benutten (dat is belangrijke kennisontwikkeling) en om te weten te komen waar ze naar toe trekken wanneer ze de Westerschelde verlaten.

\section{$5 \quad$ Kwaliteitsborging}

Wageningen Marine Research beschikt over een ISO 9001:2008 gecertificeerd kwaliteitsmanagementsysteem (certificaatnummer: 187378-2015-AQ-NLD-RvA). Dit certificaat is geldig tot 15 september 2018. De organisatie is gecertificeerd sinds 27 februari 2001. De certificering is uitgevoerd door DNV Certification B.V.. 


\section{Literatuur}

Chevolot, M., J.R. Ellis, G. Hoarau, A.D. Rijnsdorp, Wytze T. Stam, Jeanine L. Olsen (2006). Population structure of the thornback ray (Raja clavata L.) in British waters. Journal of Sea Research 56: 305316.

Craeymeersch, J.A. (1999). The use of macrobenthic communities in the evaluation of environmental change. PhD-thesis, University of Gent.

De Brye, B., de Brauwere, A., Gourgue, O., Kärnä, T., Lambrechts, J., Comblen, R., Deleersnijder, E. (2010). A finite-element, multi-scale model of the Scheldt tributaries, river, estuary and ROFI. Coastal Engineering 57: 850-863.

Dedman, S., Officer, R., Brophya, D., Clarke, M., Reid, D.G. (2015). Modelling abundance hotspots for data-poor Irish Sea rays. Ecological Modelling 313: 77-90.

Ellis, J.R, Burt, G.J., Cox, L.P.N., Kulka, D.W., Payne, A.I.L. (2008). The status and management of thornback ray Raja clavata in the south-western North Sea. ICES CM 2008/K: 13, 45 pp.

Ellis, J.R., Dulvy, N., Walls, R. \& Serena, F. (2016). Raja clavata. The IUCN Red List of Threatened Species 2016: e.T39399A103111648. 31 July 2017. http://www.iucnredlist.org/details/39399/1.

Fock, H. (2014). Patterns of extirpation. I. Changes in habitat use by thornback rays Raja clavata in the German Bight for 1902-1908, 1930-1932, and 1991-2009. Endangered Species Research 25: 197-207.

Greenway, E., K.S. Jones, G.M. Cooke (2016). Environmental enrichment in captive juvenile thornback rays, Raja clavata (Linnaeus 1758). Applied Animal Behaviour Science 182 (2016) 86-93. http://dx.doi.org/10.1016/j.applanim.2016.06.008.

Heessen, H.J.L., N. Daan \& J.R. Ellis (2015). Fish atlas of the Celtic Sea, North Sea, and Baltic Sea. Based on international research-vessel surveys. Wageningen Academic Publishers, KNNV Publishing, The Netherlands.

Humphries, N.E., S.J. Simpson, V.J. Wearmouth, D.W. Sims (2016). Two's company, three's a crowd: fine-scale habitat partitioning by depth among sympatric species of marine mesopredator. Marine Ecology Progress Series 561: 173-187. doi: 10.3354/meps11937.

Hunter, E., A.A. Buckley, C. Stewart \& J.D. Metcalfe (2005). Migratory behaviour of the thornback ray, Raja clavata, in the southern North Sea. J. Mar. Biol. Ass. U.K. 85, 1095-1105.

ICES (2016). Report of the Working Group on Elasmobranch Fishes (WGEF), 15- 24 June 2016, Lisbon, Portugal. ICES CM/ACOM:20. 26 pp.

IUCN/SSC (2013). Guidelines for Reintroductions and Other Conservation Translocations. Version 1.0. Gland, Switzerland: IUCN Species Survival Commission, viii + 57 pp.

Jongbloed, R.H., van Overzee, H.M.J., van Hal, R. (2017). Habitatgeschiktheidsanalyse voor stekelrog (Raja clavata) in Oosterschelde en Voordelta;. Wageningen Marine Research, Wageningen UR (University \& Research centre), Wageningen Marine Research rapport C059/17.

Lauria, V., M. Gristina, M.J. Attrill, F. Fiorentino \& G. Garofalo (2015). Predictive habitat suitability models to aid conservation of elasmobranch diversity in the central Mediterranean Sea. Scientific Reports | 5:13245 | DOI: 10.1038/srep13245.

Martin CS, Vaz S, Ellis JR, Lauria V, Coppin F, Carpentier A (2012). Modelled distributions of ten demersal elasmobranchs of the eastern English Channel in relation to the environment. Journal of Experimental Marine Biology and Ecology, 418-419, 91-103.

Maxwell, D.L., V. Stelzenmüller, P.D. Eastwood \& S.I. Rogers (2009). Modelling the spatial distribution of plaice (Pleuronectes platessa), sole (Solea solea) and thornback ray (Raja clavata) in UK waters for marine management and planning J ournal of Sea Research 61 (2009) 258-267.

Meire, P.M., Seys, J.J., Ysebaert, T.J., Coosen, J. (1991). A comparison of the macrobenthic distribution and community structurebetween two estuaries in SW Netherlands. Estuaries and Coasts: Spatial and Temporal Intercomparisons. M. Elliott and J.-P. Ducrotoy. Fredensborg, Olsen \& Olsen: 221230.

Poortman, S. E., (2013). Bepaling bodemschuifspanning in de Westerschelde. 1630/U13002/B/SPo, Svašek, Rotterdam 
Schoevers, M. (2013). Stroming in de Westerschelde. Inventarisatie van de informatiebehoefte en informatievoorziening. Deltares. Rapport 1207729-002-ZKS-0002, 13 december 2013.

Sguotti, C., C.P. Lynam, B. Garcia-Carreras, J.R. Ellis, G.H. Engelhard (2016). Distribution of skates and sharks in the North Sea: 112 years of change. Global Change Biology (2016) 22, 2729-2743, doi: 10.1111 /gcb. 13316 .

Van Damme, S., Struyf, E., Maris, T., Ysebaert, T., Dehairs, F., Tackx, M., Heip, C., Meire, P. (2005). Spatial and temporal patterns of water quality along the estuarine salinity gradient of the Scheldt estuary (Belgium and The Netherlands): results of an integrated monitoring approach. Hydrobiologia 540: $29-45$.

Van den Heuvel-Greve, M., Tangelder, M., Ysebaert, T., de Kluijver, M. (2016). Kolonisatie van bodemgemeenschappen van zacht substraat in de Oosterschelde en Westerschelde na uitvoering van vooroeververdediging. Notitie IMARES, Wagening UR.

Van Overzee, H.M.J., M.L. Kraan \& F.J. Quirijns (2014). Beleidsondersteunend onderzoek haaien en roggen. IMARES Rapport C009/14, $62 \mathrm{p}$.

Walker, P. \& I. Kingma (2013). Onderzoek naar haaien en roggen in Nederland in het kader van de Kaderrichtlijn Mariene Strategie. Eindrapportage fase 1: Referentiesoorten bepalen. Rapport van de Nederlandse Elasmobranchen Vereniging.

Walker, P. (1996). Ecoprofile rays and skates on the Dutch continental shelf and North Sea. Rapport RIKZ-96.005; NIOZ Publication No.: 3053. 76 pp.

Walker, P. A. \& H.J.L Heessen (1996). Long-term changes in ray populations in the North Sea. - ICES J ournal of Marine Science, 53: 1085-1093.

Walker, P. A., Howlett, G. \& Millner, R. (1997). Distribution, movement and stock structure of three ray species in the North Sea and eastern English Channel. - ICES J ournal of Marine Science, 54: 797808.

Walker, P., I. Kingma, M. van de Water, A. De Blaeij \& WJ. Strietman (2015). Onderzoek naar haaien en roggen in Nederland in het kader van de Kaderrichtlijn Mariene Strategie. Eindrapportage fase 2: Voorwaarden voor herstel van Haaien- en Roggenpopulaties in de Noordzee. Rapport van de Nederlandse Elasmobranchen Vereniging, LEI-Wageningen UR \& WING.

Walker, P.A. (1999). Fleeting images: Dynamics of North Sea Ray populations. PhD Thesis, University of Amsterdam, the Netherlands, $145 \mathrm{pp}$.

Ysebaert, T., P.M.J. Herman, P. Meire, J. Craeymeersch, H. Verbeek, C.H.R. Heip (2003). Large-scale spatial patterns in estuaries: estuarine macrobenthic communities in the Schelde estuary, NW Europe, Estuarine, Coastal and Shelf Science 57: 335-355.

Ysebaert, T., Plancke, Y., Bolle, L., De Mesel, I., Vos, G., Wielemaker, A., Van der Wal, D., Herman, P.M.J. (2009). Habitatmapping Westerschelde - Deelrapport 2: Ecologische karakteristieken en ecotopen in het subtidaal van de Westerschelde. Studie in opdracht van LTV O\&M. Report. Netherlands Institute of Ecology, Yerseke. 


\section{Verantwoording}

Rapport C028/18

Projectnummer: 4316100146

Dit rapport is met grote zorgvuldigheid tot stand gekomen. De wetenschappelijke kwaliteit is intern getoetst door een collega-onderzoeker en het verantwoordelijk lid van het managementteam van Wageningen Marine Research

Akkoord:

Dr. O.G. Bos

onderzoeker

Handtekening:

Datum:

23 april 2018

Akkoord:

Drs. J. Asjes

MT-lid Integratie

Handtekening:

Datum:

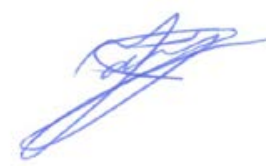

23 april 2018 


\section{Bijlage 1 IUCN/SSC richtlijnen voor herintroductie van soorten}

Selectie uit de richtlijnen van IUCN/SSC (2013) van teksten die het meest relevant zijn met het oog op een habitatgeschiktheidsanalyse ten behoeve van de introductie van gekweekte juveniele stekelroggen in de Oosterschelde. Deze selectie is niet volledig en het wordt aanbevolen ook de volledige tekst van de richtlijnen van IUCN/SSC (2013) te raadplegen.

Referentie: I UCN/ SSC (2013). Guidelines for Reintroductions and Other Conservation Translocations. Version 1.0. Gland, Switzerland: I UCN Species Survival Commission, viiii + 57 pp. (https:/ / portals.iucn.org/ library/ sites/ library/ files/ documents/ 2013-009.pdf)

\section{Section 1 I ntroduction and scope of Guidelines}

These Guidelines focus on conservation translocations, namely a translocation that yields quantifiable conservation benefit. For this purpose the beneficiaries should be the populations of the translocated species, or the ecosystems that it occupies. Situations in which there is benefit only to the translocated individuals do not meet this requirement.

\section{Section 2 Definitions and classification}

Conservation translocations can entail releases either within or outside the species' indigenous range. The indigenous range of a species is the known or inferred distribution generated from historical (written or verbal) records, or physical evidence of the species' occurrence.

1. Population restoration is any conservation translocation to within indigenous range, and comprises two activities:

a. Reinforcement is the intentional movement and release of an organism into an existing population of conspecifics.

Reinforcement aims to enhance population viability, for instance by increasing population size, by increasing genetic diversity, or by increasing the representation of specific demographic groups or stages.

\section{Section 5 Feasibility and design}

5.1.1 Basic biological knowledge 1. Necessary knowledge of any translocation candidate species should include its biotic and abiotic habitat needs, its interspecific relationships and critical dependencies, and its basic biology.

\subsubsection{Habitat}

Feasibility and design

1. While reintroduction into indigenous range is always preferable, previous indigenous range may no longer be suitable habitat depending on ecological dynamics during the extinction period.

2. The last place in which a species/population was found may not be the best habitat for returning the species.

3. Suitable habitat should meet the candidate species' total biotic and abiotic needs through space and time and for all life stages. 
5.1.3 Climate requirements

1. The climate at destination site should be suitable for the foreseeable future.

\section{Section 7 Release and implementation}

7.1 Selecting release sites and areas

A release area should:

- Meet all the species' biotic and abiotic requirements,

- Be appropriate habitat for the life stage released and all life stages of the species,

- Be adequate for all seasonal habitat needs,

- Be large enough to meet the required conservation benefit,

- Have adequate connectivity to suitable habitat if that habitat is fragmented,

- Be adequately isolated from suboptimal or non-habitat areas which might be sink areas for the population.

\section{Section 8 Monitoring and continuing management}

\subsection{Monitoring}

3. The monitoring programme (Guidelines Section 4.3) is the means to measure the performance of released organisms against objectives, to assess impacts, and provide the basis for adjusting objectives or adapting management regimes or activating an exit strategy.

- Demographic performance Key aspects for any translocation should include monitoring of population growth and/or spread; more intensive monitoring to estimate individual survival, reproduction and dispersal may be needed depending on circumstances.

- Behavioural monitoring Monitoring the behaviour of translocated individuals can be a valuable, early indicator of translocation progress; but its value depends on comparative data from either comparable natural populations or the same individuals before removal from their source population.

\section{Annex 5 Feasibility and design}

3. Background ecological knowledge should include biotic and abiotic habitat requirements, intraspecific variation, adaptations to local ecological conditions, seasonality and phenology, dispersal, and interspecific relationships including feeding, predation, disease, commensalism, symbioses and mutualisms.

15. As even the most detailed habitat assessments may not capture the full range of environmental variation during the lifespan of individuals of the focal species, the loss through death or dispersal of translocated individuals at some sites or in particular years should be expected. 


\section{Bijlage 2 Biologie, verspreiding en habitat- eisen van stekelrog}

Deze bijlage is overgenomen uit Jongbloed et al. (2017) en omwille van de zelfstandige leesbaarheid van deze rapportage hier ook opgenomen. Er wordt een kort overzicht gegeven van de biologie en de verspreiding, inclusief de migratie, van de stekelrog in de Noordwest-Europese zeeën vanaf 1900. Hierbij is geen compleetheid nagestreefd. Een deel van deze informatie is van belang bij de beoordeling van de potentiële habitatgeschiktheid van de stekelrog in de Westerschelde.

\section{Ecologie van de stekelrog}

De stekelrog heeft als vissoort een lage groeisnelheid, lage vruchtbaarheid en een hoge leeftijd voor het bereiken van volwassenheid. Deze eigenschappen maken deze soort gevoelig voor verhoogde mortaliteit, door bijvoorbeeld visserij (Heessen et al., 2015; Walker \& Kingma, 2013). De stekelrog is geclassificeerd als bijna bedreigd (near threatened) in de IUCN database (Ellis et al., 2016).

De stekelrog is een epibenthische kraakbeenvis die het grootste deel van de tijd gedeeltelijk is ingegraven in de bodem.

In experimenten met gemerkte stekelroggen, uitgevoerd tussen 1959 en 1976, zijn verspreiding en bewegingen van stekelroggen geanalyseerd en beschreven door Walker et al. (1997). Zij vonden dat stekelroggen in de Noordzee behoorden tot één bestand en die in het Kanaal tot een ander bestand. Na vrijlating bleven de gemerkte stekelroggen binnen ca. 30-50 zeemijl in de Noordzee en binnen ca. 1015 zeemijl in het Kanaal. Adulte stekelroggen migreren van offshore, relatief diep (ca. $30 \mathrm{~m}$ ) water in de winter naar inshore, ondiep (ca. $10 \mathrm{~m}$ ) water in de zomer, waarschijnlijk voor de voortplanting.

Belangrijke eigenschappen van de stekelrog zijn samengevat door Walker \& Kingma (2013) en overgenomen in onderstaande tabel.

Tabel B.1. Overzicht van kenmerken van de stekelrog.

\begin{tabular}{|l|l|}
\hline Latijnse naam & Raja clavata \\
\hline Nederlandse naam & Stekelrog \\
\hline Lengte (geboren) $(\mathrm{cm})$ & $11-13$ \\
\hline Max lengte volwassen $(\mathrm{cm})$ & 130 \\
\hline Verspreiding & Bijna overal \\
\hline Habitat & Kustwateren \\
\hline Indeling & Demersaal \\
\hline Dieet & Kreeftachtigen en vissen \\
\hline Migratie & Seizoensgebonden migratie \\
\hline Voortplanting & Ovipaar \\
\hline Duur draagtijd (maanden) & $4-6$ \\
\hline Aantal jongen & $48-78$ \\
\hline Volwassen drempel (jaar) & $7-9$ \\
\hline Bevissing & Commercieel en recreatief bevist \\
\hline
\end{tabular}




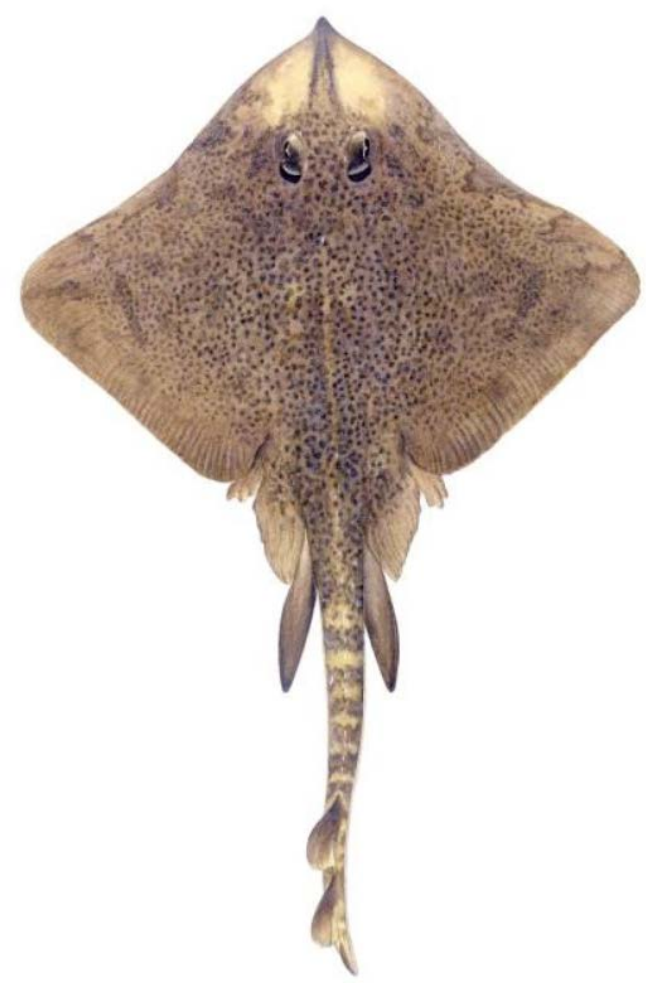

Figuur B.1 Stekelrog (Raja clavata) Bron: Walker et al. (2015)

\section{Historische verspreiding van de stekelrog in de Noordzee}

Een historisch overzicht wordt gegeven in een ecoprofiel voor roggen in de Noordzee (Walker, 1996). Halverwege de vorige eeuw trad een afname van de stekelrog op (Walker \& Heessen, 1996). De Zuiderzee was het belangrijkste paai- en opgroeigebied voor de stekelrog van de Nederlandse wateren. In de Nederlandse kustwateren en zuidelijke estuaria werden vroeger voornamelijk stekelroggen (90\%) en pijlstaartroggen (10\%) gevangen. De Zeeuwse estuaria waren belangrijker dan die in Zuid-Holland of de Waddenzee (Walker, 1996). De visserij vond voornamelijk plaats gedurende de lente en de zomer, waarna de roggen naar dieper water migreerden. De achteruitgang in aantallen voltrok zich hier later dan in de Waddenzee. Tot de jaren zestig werd gevist op stekelrog, maar tussen 1979 en 1985 werden in Zeeuwse estuaria geen stekelroggen meer gevangen door beroepsvissers (Walker \& Kingma, 2013).

Tegenwoordig concentreert de stekelrog zich in het zuidwestelijk deel van de Noordzee. De abundantie aldaar is toegenomen in de afgelopen 5 jaar (Walker \& Kingma, 2013; Sguotti et al., 2016). ICES (2016) concludeert dat de stekelrog hoofdzakelijk stabiel/toenemend is in recente jaren wanneer wordt uitgegaan van visserij onafhankelijke gegevens van de International Bottom Trawl Survey (IBTS) in winter en zomer, en van verschillende boomkorsurveys (in zomer).

Sguotti et al. (2016) bestudeerden lange termijn veranderingen in de verspreiding en abundantie van roggen in de zuidelijke Noordzee, gebaseerd op extensieve historische tijdseries (1902-2013) van visserij-onafhankelijke survey data. De stekelrog vertoonde over die periode een significante afname. Binnen de Noordzee was de dichtheid hoger in het zuidwestelijke en noordwestelijke deel ten opzichte van het oostelijke deel (zie Figuur B.2). De Zeeuwse deltawateren vallen onder het oostelijke deel. Dit is in overeenstemming met de constateringen van de ICES Working Group on Elasmobranch Fishes (ICES, 2016) dat de stekelrog in de eerste decennia van de 20ste eeuw breder verspreid was over de zuidelijke Noordzee, met hoge abundantie in de zuidwestelijke Noordzee en in de Duitse Bocht, ten noorden van Helgoland. De soort is verdwenen uit de zuidoostelijke Noordzee (Duitse Bocht), en vangsten in de Zuidelijke Bocht zijn beperkt tot het westelijke deel. 


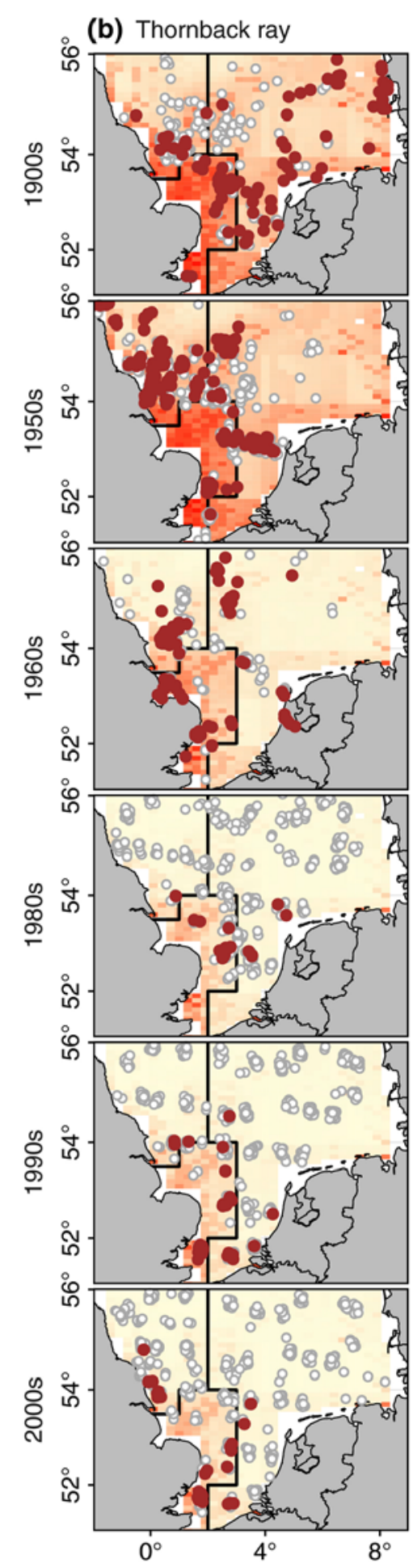

Incidence

$0 \%$

$50 \%$

$100 \%$

Figuur B.2 Veranderingen in gemodelleerde ruimtelijke verspreiding van stekelrog op de Noordzee. Kaarten tonen de voorspelde verspreidingspatronen in zes goed bemonsterde decennia: symbolen duiden survey trekken aan (rood gevuld als tenminste 1 individu was gevonden, anders ongevuld) en graduele achtergrond kleuren tonen het voorspelde voorkomen. Bewerking van een kaart uit Sguotti et al. (2016).

\section{Recente verspreiding van de stekelrog op de internationale Noordzee}

Het verspreidingsgebied en abundantie van de stekelrog is gedurende de laatste eeuw afgenomen, met een resterende concentratie in de zuidwestelijke Noordzee en een uitbreiding tot in het Kanaal (zie Figuur B.3). In recente jaren zijn de survey catch trends in ICES Divisies 4.c (Zuidelijke Noordzee) en 7.d (Oostelijke Kanaal) stabiel/toenemend. De status in Divisies 4.a-b is onzeker (ICES, 2016). 


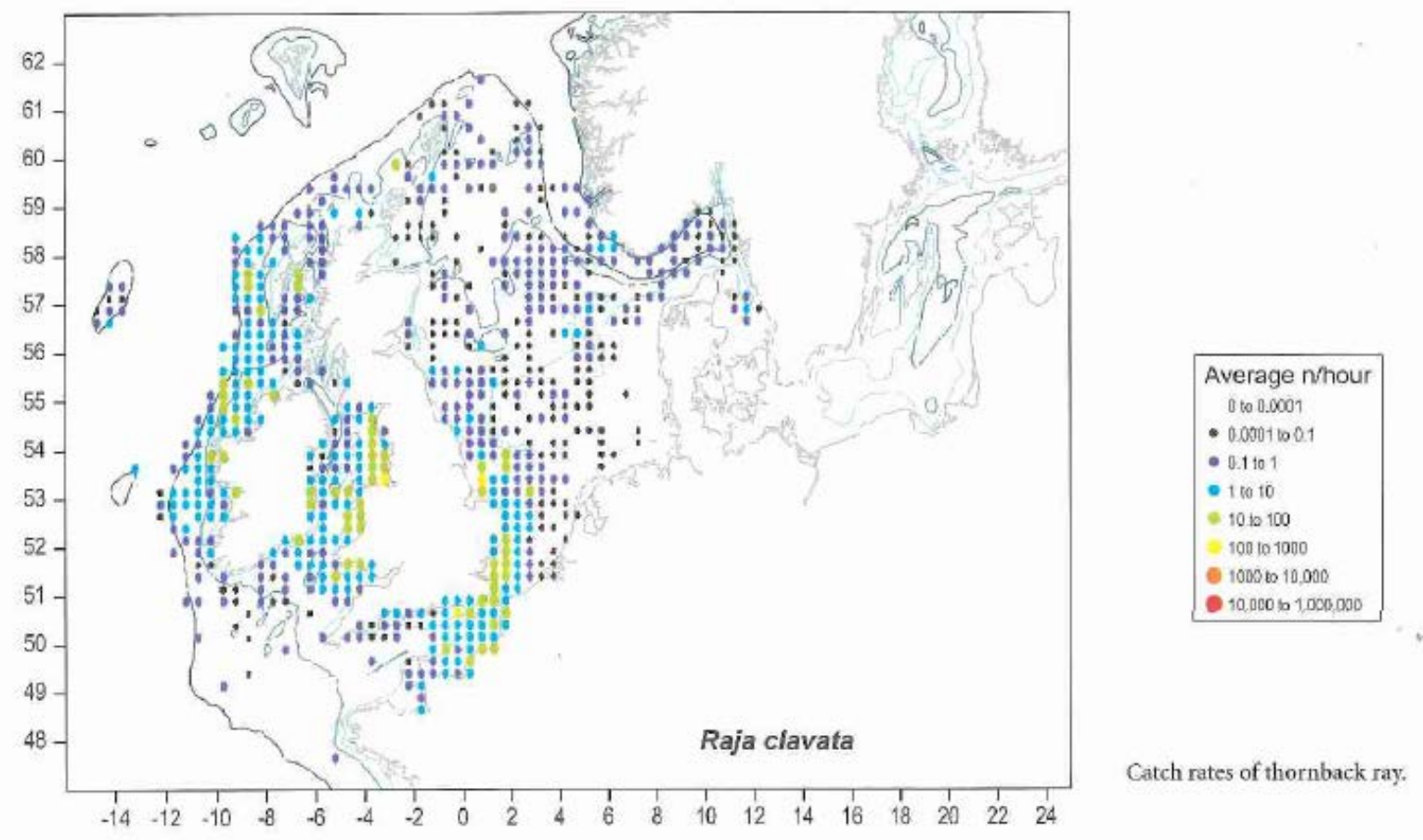

Figuur B.3 Vangst (in gemiddeld aantal per uur) van stekelrog in surveys in de ecoregio's Noordzee, Keltische Zee, Oostzee, in de periode 1977-2013. Bron: Heessen et al. (2015)

\section{Migratie van de stekelrog}

Er zijn verschillende experimenten uitgevoerd naar de ruimtelijke en temporele verspreiding en eventuele seizoenmigratie van stekelroggen in en rond de Noordzee (Walker et al., 1997; Hunter et al. 2005; Chevolot et al., 2006; Humphries et al., 2016). Hierbij zijn de stekelroggen gemerkt met conventionele externe merken of met data storage tags (DST). De DST geven veel gedetailleerdere informatie over de migratieafstanden. Er treedt seizoenmigratie op, waarbij het overgrote deel van de stekelroggen binnen enkele tientallen kilometers blijft van de locatie waar de roggen waren gemerkt (het Theems estuarium: Walker et al., 1997; Hunter et al., 2005). Een klein deel maakt echter lange tochten, meestal tot $130 \mathrm{~km}$ of soms veel meer. Dit laatste bleek uit een individuele stekelrog die in het Theems estuarium was gemerkt met een DST en in de herfst migreerde naar het zuidelijke deel van de centrale Noordzee en daar rondzwierf. In het voorjaar keerde deze rog terug naar het Theems estuarium om te paren (Hunter et al., 2005). De afstanden die deze rog aflegde tijdens de migratie waren dus aanzienlijk. Met name de DST-studies met individuele stekelroggen maken duidelijk dat er seizoenmigratie optreedt met de tendens om terug te keren naar belangrijke habitats voor paren en het afzetten van de eieren (Heessen et al., 2015). Het is dus de vraag of de Voordelta, de Oosterschelde en de Westerschelde gebieden zijn of kunnen worden die ook de rol van die belangrijke habitats kunnen spelen.

\section{Habitateisen}

Estuaria en kustgebieden zijn belangrijke habitats voor vele soorten haaien en roggen. Factoren die habitats minder geschikt kunnen maken zijn onder andere: infrastructurele werken, eutrofiering, verlies aan biobouwers, zoals zeegras en mosselbanken (Walker et al., 2015).

Er zijn bij roggen drie levensfasen te onderscheiden die specifieke eisen aan ecologische habitats stellen: (a) eileggebieden; (b) kinderkamergebieden; (c) gebieden voor grote samenscholingen voor foerageren en paren. Er is weinig bekend over de eileggebieden, alhoewel zich in delen van de zuidelijke Noordzee, zoals het Theems estuarium, grote aantallen juveniele stekelroggen bevinden en daardoor eileggebieden worden verwacht in het buiten Theems estuarium en The Wash (Walker, 1996). De exacte habitateisen van elk van deze drie specifieke habitats zijn dus niet bekend. Dat betekent dat de Oosterschelde en Voordelta niet kunnen worden beoordeeld op geschiktheid voor eileglocaties, opgroeilocaties, samenscholingslocaties voor voortplanting of foerageren. 
Stekelroggen komen voor binnen bepaalde grenzen aan abiotische factoren (bodemdynamiek, waterdiepte, saliniteit, watertemperatuur, stroomsnelheid (i.v.m. retentie van eikapsels en juvenielen) en biotische factoren (voldoende voedsel, zoals kreeftachtigen, weinig predatie, weinig uitval door ziektes, populatie groot genoeg voor voldoende reproductie). Op basis van de habitateisen van de stekelrog, en de habitatkarakteristieken van de Oosterschelde en Voordelta, is nagegaan wat de mogelijkheden zijn voor de ontwikkeling van een stekelrogpopulatie in die gebieden.

Bodemdynamiek en stroomsnelheid en de aanwezigheid van structuren op de bodem zijn waarschijnlijk belangrijke factoren voor de overleving van eikapsels en jongen van roggen. Onder deze omstandigheden is de kans op het wegspoelen van de eikapsels en de jongen kleiner. Bovendien is er dan meer bescherming tegen predatoren.

Vier life-history-processen bepalen in belangrijke mate de voorwaarden voor een duurzame ontwikkeling van een populatie van de stekelrog: overleving, groei, reproductie en rekrutering. Er is echter nog erg weinig bekend over de invloed van habitatkenmerken op deze life-history-processen. Onderhavige studie heeft zich daarom alleen gericht op de verspreiding en abundantie van stekelroggen en de relatie met abiotische en biotische omgevingsfactoren.

Er zijn een tiental publicaties geselecteerd die goed kunnen worden gebruikt voor de huidige studie naar de habitatgeschiktheid van gebieden voor de stekelrog. Deze publicaties worden hieronder besproken. Hierbij wordt onderscheid gemaakt tussen abiotische en biotische factoren die worden beschreven in verschillende paragrafen. De studies hebben betrekking op verschillende gebieden. De focus lag op de zuidelijke Noordzee vanwege de vergelijkbaarheid met de Oosterschelde, Voordelta en Westerschelde. Echter daar het aantal studies beperkt bleek te zijn, zijn ook studies over andere gebieden geselecteerd, zoals andere delen van de Noordzee, het Kanaal, Keltische Zee, I erse Zee, Middellandse Zee. In de meeste studies is de habitatgeschiktheid gemodelleerd met behulp van correlaties tussen de presentie van stekelroggen en de omgevingsfactoren.

\section{Abiotische factoren}

Martin et al. (2012) gebruikten Generalised Linear Models (GMLs), gecombineerd met GIS om de habitats van stekelrog in het Kanaal te voorspellen. Dit was gebaseerd op jaarlijkse visserijonafhankelijke bottom trawl surveys gedurende een periode van 21 jaar. Habitat modelberekeningen leverden gemiddelde dichtheidsniveau's voor de stekelrog. De belangrijkste ( $1^{\mathrm{e}}$ orde) voorspellers voor stekelroghabitats in het Kanaal waren diepte, bodemschuifspanning en saliniteit, gevolgd door $2^{\mathrm{e}}$ orde voorspellers bodemsedimenttype en watertemperatuur. Stekelrog vertoont in het Kanaal een breed habitatgebruik met een brede range voor de waarden van bovengenoemde abiotische factoren. Dit habitatgebruik is wel sterk leeftijdsafhankelijk, waarbij Martin et al. (2012) onderscheid maken tussen enerzijds pasgeborenen en jongen en anderzijds subadult en adult. De pasgeborenen en jongen (0-1 jaar groep) prefereren ondiepe kustwateren, beschermd tegen getijdestromingen en met zachter sediment (slib en zand). De subadulten en adulten (2+ groep) prefereren harde sedimenten (gravel en kiezels), wat dieper water met matige tot sterke getijdenstroming. Dit is consistent met eerdere studies in dit gebied en in andere gebieden.

Jonge stekelroggen zijn waarschijnlijk beperkt in hun zwemcapaciteiten en daardoor extra kwetsbaar voor predatoren in ongeschikte habitats. Ondiepe kustwateren zijn wel gunstig want deze bieden bescherming bieden tegen predatie, overvloedig voedselaanbod en warmer water waarmee de groei wordt versneld. Martin et al. (2012) concluderen dat voor de stekelrog meer kennis nodig is voordat ruimtelijk management op betrouwbare wijze kan worden toegepast voor deze soort.

Maxwell et al. (2009) benutten survey data van een 14 jarige periode om met regressiemodellen en geostatistische tools een verspreidingskaart voor stekelrog in drie hydrografische regio's rond de UK (Engelse deel van het Kanaal, delen van I erse Zee en Keltische zee) te construeren. Zij betrokken hierbij de omgevingsvariabelen: diepte, bodemtemperatuur, zeebodemschuifspanning en sediment type, als voorspellers. Het voorkomen van de stekelrog was positief gerelateerd aan ondiepe gebieden, een zeebodemschuifspanning tussen 0 en $1.5 \mathrm{~N} / \mathrm{m}^{2}$, en de aanwezigheid van zandig sediment. De voorspelde aanwezigheid was in goede overeenstemming met de survey waarnemingen. 
De stekelrogmodellen waren vergelijkbaar voor het Engelse Kanaal en de Keltische Zee met de conclusie dat diepte, zeebodemschuifspanning, temperatuur voorspellers zijn van de verspreiding van stekelroggen. De Ierse Zee toonde een verschil met het Engelse Kanaal en de Keltische Zee, want voor de lerse Zee is temperatuur geen voorspeller, maar sediment type wel een voorspeller van de verspreiding van stekelroggen. De auteurs vermelden dat dit laat zien dat men voorzichtig moet zijn met de modellering van de verdeling van de soort over een groter geografisch gebied en de extrapolatie naar andere gebieden.

Er zijn overeenkomsten en verschillen tussen de conclusies van Martin et al. (2012) en Maxwell et al. (2009) m.b.t. de stekelrog in het Kanaal. Beide concluderen dat diepte en zeebodemschuifspanning zeer belangrijke voorspellers zijn. Martin et al. (2012) noemen daarbij nog saliniteit, terwijl Maxwell et al. (2009) temperatuur noemen. De verschillen in de opzet van de analyses kunnen dit verschil mogelijk verklaren. Martin et al. (2012) hebben namelijk het hele gebied van het Kanaal bestudeerd, terwijl Maxwell et al. (2009) alleen het Engelse deel van het Kanaal hebben bestudeerd. Daarnaast hebben Martin et al. (2012) in tegenstelling tot Maxwell et al. (2009) onderscheid gemaakt tussen twee ontwikkelingsstadia van de stekelrog.

Sguotti et al. (2016) vonden met een habitatmodel een nauwe associatie van de stekelrog met warmer zeewater (jaargemiddelde temperatuur in bovenste deel van de range van 9.5 tot $12{ }^{\circ} \mathrm{C}$ ), waarbij ondieper water (hoofdzakelijk 5-40 m), en hard, grof, gemengd en onbekende sedimenten werden geprefereerd. De relatie tussen bodemschuifspanning en saliniteit en het voorkomen van de stekelrog is niet door Sguotti et al. (2016) onderzocht.

Hunter et al. (2005) onderzochten de ruimtelijke en temporele verspreiding van in het Theems estuarium gevangen stekelroggen door deze te merken met data storage tags (DSTs) of met plastic tags. Ongeveer de helft van de tags werd geretourneerd. Bijna alle teruggevangen stekelroggen waren afkomstig uit het Theems estuarium. De gemiddelde dagtemperatuur en zeebodemdiepte werden geregistreerd. Beide parameters vertoonden een jaarlijkse cyclus. De maximum en minimum temperaturen waren respectievelijk $22.2^{\circ} \mathrm{C}$ en $4.9{ }^{\circ} \mathrm{C}$, terwijl de diepte varieerde tussen 60 en $1 \mathrm{~m}$. De roggen bevonden zich gedurende herfst en winter in dieper water van 20-35m en ook $>35 \mathrm{~m}$. daarna migreerden ze in het voorjaar naar ondiep water ( $<20 \mathrm{~m}$ diepte) en gedurende de reproductieperiode (maart - oktober) bevonden de meeste roggen zich in water ondieper dan $10 \mathrm{~m}$.

De aanwezigheid van stekelroggen in de ondiepe estuaria en de Waddenzee in de zomermaanden wijst op de voorkeur voor warm water en hun tolerantie voor estuariën water met een laag zoutgehalte. De verspreiding van roggen wordt niet duidelijk beïnvloed door waterstroming (Walker, 1996).

Fock (2014) analyseerde de gegevens van de verspreiding van stekelroggen in de Duitse Bocht gedurende 3 perioden tussen 1902 en 2009. Hij concludeerde dat in de periode 1902-1908, toen de visserijdruk laag was, stekelroggen voorkwamen in habitats geassocieerd met voedselgebieden. Er was toen een negatief verband tussen stekelrogverspreiding en gravel- en slibgronden. In de recentere perioden (bijvoorbeeld 1930-1932) was de visserijdruk groot en werd minder riskant habitat door stekelroggen bezet, dat zwakker geassocieerd was met foerageergebieden, zonder verband met sedimenttype. Daarna werd de visserijdruk zo groot dat de stekelrog uiteindelijk verdween (vanaf 1991). Dit illustreert dat habitatgebruik door de stekelrog niet de voorkeur van de stekelrog hoeft te weerspiegelen in aanwezigheid van een grote visserijdruk.

Humphries et al. (2016) onderzochten de geprefereerde diepterange van 43 stekelroggen in het Kanaal met behulp met electronic data storage tags. Er was een duidelijke geprefereerde relatief nauwe diepterange tussen 5 en $20 \mathrm{~m}$. De meeste exemplaren hielden zich op rond $10 \mathrm{~m}$ diepte en de gemiddelde diepte was $18 \mathrm{~m}$. Er was enig bewijs voor een verschuiving met seizoen met een iets grotere diepte gedurende de zomer. De diepte tijdens een etmaal varieerde relatief weinig en was iets dieper tijdens de dag en iets ondieper tijdens de nacht. De watertemperatuur waar de getagde stekelroggen zich ophielden varieert ca. $7^{\circ} \mathrm{C}$ gedurende het jaar, met de hoogste temperatuur van $15.5^{\circ} \mathrm{C}$ eind zomer en de laagste temperatuur van $8.5^{\circ} \mathrm{C}$ eind winter. Het studiegebied betreft goed gemengde wateren die geen afname van temperatuur met diepte hebben zoals op veel andere locaties geldt. Er is geen relatie 
tussen diepte en temperatuur gevonden. Voor de gemerkte dieren lijkt daarom temperatuur geen sturende factor en ook geen gevolg te zijn van habitatvoorkeur. De diepte is wel een sturende factor voor de stekelrog in dit gebied.

De informatie over roggen is data arm in vergelijking met commercieel geëxploiteerde beenvissen. Dit hindert het inzicht in de abundantie verspreiding en de relatie hiervan met de omgevingsfactoren voor zowel adulte als juveniele levensstadia. Dedman et al. (2015) hebben een methode toegepast die geschikt is voor data arme soorten zoals roggen in de Ierse Zee. Dit is de delta log-normal boosted regression trees. Hieruit bleek dat de verspreiding van de stekelrog werd gestuurd door een voorkeur voor zand en grovere substraten, hogere saliniteiten, hogere temperaturen, grotere stroomsnelheden. Vergelijking tussen abundantieverspreiding en locaties van commerciële visserij indiceerde dat de belangrijkste hotspots van roggen zich buiten de belangrijkste commerciële visserijgebieden bevinden.

In de centrale Middellandse Zee bleken 5 omgevingsfactoren de habitatgeschiktheid voor stekelroggen te sturen, namelijk diepte, watertemperatuur, saliniteit, sediment type en ruwheid van de zeebodem. Stekelroggen prefereren de ondiepe wateren van kustgebieden en bepaalde banken, alsmede zeebodem met zachte substraten Lauria et al. (2015).

Juveniele stekelroggen, met een leeftijd tussen 13 en 21 maanden en een vin tot vinbreedte tussen 15 en $32 \mathrm{~cm}$, zijn door Greenway et al. (2016) getest in aquaria in hun keuze en gedrag met betrekking tot type en kleur van substraat en gebruik van schuilplaats. Deze dieren bleken zacht geel zand te prefereren boven grof gravel. Kunstmatige en natuurlijke schuilplaatsen werden niet gebruikt.

Een compilatie van de milieuomgevingsfactoren en de bijbehorende waarden uit de studies die hierboven zijn beschreven studies is gemaakt in B. 2 .

Tabel B.2 Waarden voor abiotische milieufactoren als sturende factoren in studies naar habitatgeschiktheid van stekelroggen in diverse gebieden in en nabij de zuidelijke Noordzee

\begin{tabular}{|c|c|c|c|c|}
\hline $\begin{array}{l}\text { Milieu- } \\
\text { factor }\end{array}$ & Gebied & $\begin{array}{l}\text { Waarden in } \\
\text { onderzochte } \\
\text { gebied }\end{array}$ & $\begin{array}{l}\text { Waarden door stekelrog } \\
\text { geprefereerd }\end{array}$ & Referentie \\
\hline Diepte & $\begin{array}{l}\text { Engels Kanaal } \\
\text { (UK deel) }\end{array}$ & $0-82 m$ & Ondiepe gebieden* & $\begin{array}{l}\text { Maxwell et al. } \\
(2009)\end{array}$ \\
\hline Diepte & Ierse Zee & $8-134 m$ & Ondiepe gebieden & $\begin{array}{l}\text { Maxwell et al. } \\
(2009)\end{array}$ \\
\hline Diepte & $\begin{array}{l}\text { Keltische Zee } \\
\text { (UK deel) }\end{array}$ & $8-113 m$ & Ondiepe gebieden & $\begin{array}{l}\text { Maxwell et al. } \\
(2009)\end{array}$ \\
\hline Diepte ${ }^{1}$ & Engels Kanaal & $0-82 m$ & $\begin{array}{l}\text { Brede range en leeftijdsafhankelijk: } \\
\text { ondiep (juv.) tot dieper ( } 82 \mathrm{~m} \text { ) (ad.) }\end{array}$ & $\begin{array}{l}\text { Martin et al. } \\
(2012)\end{array}$ \\
\hline Diepte & Noordzee & $0-120 \mathrm{~m}$ & Ondiep (voornamelijk 5-40 m) & $\begin{array}{l}\text { Sguotti et al. } \\
(2016)\end{array}$ \\
\hline Diepte & $\begin{array}{l}\text { Middellandse Zee } \\
\text { (centraal) }\end{array}$ & $1-1793$ & Ondiep & $\begin{array}{l}\text { Lauria et al. } \\
(2015)\end{array}$ \\
\hline Diepte & lerse Zee & Niet gerapporteerd & & $\begin{array}{l}\text { Dedman et al. } \\
(2015)\end{array}$ \\
\hline Diepte & $\begin{array}{l}\text { Engels Kanaal } \\
\text { (west) }\end{array}$ & $0-80 m$ & $\begin{array}{l}\text { 5-20 m met gemiddelde van } 18 \mathrm{~m} \\
\text { en max. abundantie rond } 10 \mathrm{~m}\end{array}$ & $\begin{array}{l}\text { Humphries et al } \\
(2016)\end{array}$ \\
\hline Diepte & $\begin{array}{l}\text { Zuidelijke } \\
\text { Noordzee }\end{array}$ & Niet gerapporteerd & $\begin{array}{l}20-35 \mathrm{~m} \text { gedurende herfst en } \\
\text { winter; < } 20 \mathrm{~m} \text { gedurende voorjaar } \\
\text { en zomer }\end{array}$ & $\begin{array}{l}\text { Hunter et al. } \\
(2005)\end{array}$ \\
\hline Diepte \# & Duitse Bocht & Niet gerapporteerd & Ondiep & Fock (2014) \\
\hline $\begin{array}{l}\text { Bodemschuifs } \\
\text { panning }\end{array}$ & $\begin{array}{l}\text { Engels Kanaal } \\
\text { (UK deel) }\end{array}$ & $0.1-3.0 \mathrm{~N} / \mathrm{m} 2$ & $\begin{array}{l}\text { Bodemschuifspanning tussen } 0 \text { en } \\
1.5 \mathrm{~N} / \mathrm{m} 2\end{array}$ & $\begin{array}{l}\text { Maxwell et al. } \\
(2009)\end{array}$ \\
\hline $\begin{array}{l}\text { Bodemschuifs } \\
\text { panning }\end{array}$ & Ierse Zee & $0.02-3.0 \mathrm{~N} / \mathrm{m} 2$ & $\begin{array}{l}\text { Bodemschuifspanning tussen } 0 \text { en } \\
1.5 \mathrm{~N} / \mathrm{m} 2\end{array}$ & $\begin{array}{l}\text { Maxwell et al. } \\
(2009)\end{array}$ \\
\hline
\end{tabular}




\begin{tabular}{|c|c|c|c|c|}
\hline $\begin{array}{l}\text { Milieu- } \\
\text { factor }\end{array}$ & Gebied & $\begin{array}{l}\text { Waarden in } \\
\text { onderzochte } \\
\text { gebied }\end{array}$ & $\begin{array}{l}\text { Waarden door stekelrog } \\
\text { geprefereerd }\end{array}$ & Referentie \\
\hline $\begin{array}{l}\text { Bodemschuifs } \\
\text { panning }\end{array}$ & $\begin{array}{l}\text { Keltische Zee } \\
\text { (UK deel) }\end{array}$ & $0.01-3.0 \mathrm{~N} / \mathrm{m} 2$ & $\begin{array}{l}\text { Bodemschuifspanning tussen } 0 \text { en } \\
1.5 \mathrm{~N} / \mathrm{m} 2\end{array}$ & $\begin{array}{l}\text { Maxwell et al. } \\
(2009)\end{array}$ \\
\hline $\begin{array}{l}\text { Bodemschuifs } \\
\text { panning }{ }^{1}\end{array}$ & Engels Kanaal & $0-3 \mathrm{~N} / \mathrm{m} 2$ & $\begin{array}{l}\text { Brede range en leeftijdsafhankelijk } \\
\text { van zwak (juv.) tot intermediair tot } \\
\text { sterke getijdestromingen (adults) }\end{array}$ & $\begin{array}{l}\text { Martin et al. } \\
(2012)\end{array}$ \\
\hline Saliniteit ${ }^{1}$ & Engels Kanaal & 32.4-34.9 ppt & $\begin{array}{l}\text { Vrij breed (iets lagere saliniteit voor } \\
\text { juvenielen) }\end{array}$ & $\begin{array}{l}\text { Martin } \\
(2012)\end{array}$ et al. \\
\hline Saliniteit & $\begin{array}{l}\text { Middellandse Zee } \\
\text { (centraal) }\end{array}$ & $37.9-38.1$ & Variabel (polynoom) & $\begin{array}{l}\text { Lauria et al. } \\
(2015)\end{array}$ \\
\hline Saliniteit & lerse Zee & $\begin{array}{l}\text { Niet gerapporteerd } \\
\text { (check suppl. data) }\end{array}$ & Hoge saliniteit (piek bij 34.5ppm) & $\begin{array}{l}\text { Dedman et al. } \\
(2015)\end{array}$ \\
\hline $\begin{array}{l}\text { Temperatuur } \\
\text { (bodem) }\end{array}$ & $\begin{array}{l}\text { Engels Kanaal } \\
\text { (UK deel) }\end{array}$ & $12.7-19.0^{\circ} \mathrm{C}$ & Niet gerapporteerd & $\begin{array}{l}\text { Maxwell et al. } \\
(2009)\end{array}$ \\
\hline $\begin{array}{l}\text { Temperatuur } \\
\text { (bodem) }\end{array}$ & $\begin{array}{l}\text { Keltische Zee } \\
\text { (UK deel) }\end{array}$ & $9.8-17.9{ }^{\circ} \mathrm{C}$ & Niet gerapporteerd & $\begin{array}{l}\text { Maxwell et al. } \\
(2009)\end{array}$ \\
\hline $\begin{array}{l}\text { Temperatuur } \\
\text { (zeewateropp } \\
\text { ervlakte })^{2}\end{array}$ & Engels Kanaal & $\begin{array}{l}\text { alleen gerapporteerd } \\
\text { voor oktober: } 14.7- \\
16.5^{\circ} \mathrm{C}\end{array}$ & Niet gerapporteerd & $\begin{array}{l}\text { Martin et al. } \\
(2012)\end{array}$ \\
\hline $\begin{array}{l}\text { Temperatuur } \\
\text { (zeewateropp } \\
\text { ervlakte) }\end{array}$ & Noordzee & $9.5-12{ }^{\circ} \mathrm{C}$ & Warm & $\begin{array}{l}\text { Sguotti et al. } \\
(2016)\end{array}$ \\
\hline $\begin{array}{l}\text { Temperatuur } \\
\text { (zeewateropp } \\
\text { ervlakte) }\end{array}$ & $\begin{array}{l}\text { Middellandse Zee } \\
\text { (centraal) }\end{array}$ & $17.6-20.9^{\circ} \mathrm{C}$ & Warm & $\begin{array}{l}\text { Lauria et al. } \\
(2015)\end{array}$ \\
\hline $\begin{array}{l}\text { Temperatuur } \\
\text { (zeewater) }\end{array}$ & lerse Zee & $\begin{array}{l}\text { Niet gerapporteerd } \\
\text { (check suppl. data) }\end{array}$ & Warm & $\begin{array}{l}\text { Dedman et al. } \\
(2015)\end{array}$ \\
\hline $\begin{array}{l}\text { Temperatuur } \\
\text { (zeewater) }\end{array}$ & $\begin{array}{l}\text { Zuidelijke } \\
\text { Noordzee }\end{array}$ & Niet gerapporteerd & $\begin{array}{l}\text { tussen } 6 \text { (einde winter) en } 18.5{ }^{\circ} \mathrm{C} \\
\text { (einde zomer) }\end{array}$ & $\begin{array}{l}\text { Hunter et al. } \\
(2005)\end{array}$ \\
\hline $\begin{array}{l}\text { Sediment } \\
\text { type }\end{array}$ & lerse Zee & $\begin{array}{l}\text { Slib }(11.5 \%), \text { zand } \\
(61.2 \%), \text { gravel } \\
(25.8 \%), \text { gemengd } \\
(1.5 \%)\end{array}$ & Zandig sediment & $\begin{array}{l}\text { Maxwell et al. } \\
(2009)\end{array}$ \\
\hline $\begin{array}{l}\text { Sediment } \\
\text { type }^{2}\end{array}$ & Engels Kanaal & $\begin{array}{l}\text { Slib, fijn zand, grof } \\
\text { zand, gravel, kiezels }\end{array}$ & $\begin{array}{l}\text { Brede range (slib, fijn zand, grof } \\
\text { zand, gravel, kiezels) en } \\
\text { leeftijdsafhankelijk van slib en } \\
\text { zandig (juv. stekelrog) tot gravel } \\
\text { and kiezels (ad. stekelrog) }\end{array}$ & $\begin{array}{l}\text { Martin et al. } \\
(2012)\end{array}$ \\
\hline $\begin{array}{l}\text { Sediment } \\
\text { type }\end{array}$ & Noordzee & $\begin{array}{l}\text { Slib tot zandig slib, } \\
\text { zand tot slibbig zand, } \\
\text { grof sediment, } \\
\text { gemengd sediment, } \\
\text { stenen of harde } \\
\text { substraten, onbekend } \\
\text { sediment }\end{array}$ & $\begin{array}{l}\text { Gemengd, onbekend > stenig, grof } \\
\text { zand > zand, slib }\end{array}$ & $\begin{array}{l}\text { Sguotti et al. } \\
(2016)\end{array}$ \\
\hline $\begin{array}{l}\text { Sediment } \\
\text { type }\end{array}$ & lerse Zee & $\begin{array}{l}\text { Niet gerapporteerd } \\
\text { (check suppl. data) }\end{array}$ & Zand en grovere substraten & $\begin{array}{l}\text { Dedman et al. } \\
(2015)\end{array}$ \\
\hline $\begin{array}{l}\text { Sediment } \\
\text { type } \#\end{array}$ & Duitse Bocht & $\begin{array}{l}\text { Slib, zand, slibbig } \\
\text { zand, en gravel }\end{array}$ & $\begin{array}{l}\text { Zand in afwezigheid van grote } \\
\text { bodemvisserijdruk }\end{array}$ & Fock (2014) \\
\hline $\begin{array}{l}\text { Tijdstrend } \\
\text { (decade) }\end{array}$ & Noordzee & $1900-2014$ & Afname & $\begin{array}{l}\text { Sguotti et al. } \\
(2016)\end{array}$ \\
\hline
\end{tabular}


* publicatie noemt geen exacte dieptes

Er is getracht uit Tabel B. 2 een algemene lijn te destilleren voor elke van belang zijnde omgevingsfactor. Dit blijkt voor 3 van de 5 factoren complex te zijn, vanwege de geconstateerde verschillen. Deze factoren zijn diepte, watertemperatuur en sediment type.

Bijvoorbeeld in geval van het sedimenttype prefereren adulte stekelroggen in enkele gebieden, zoals Ierse Zee (Maxwell et al., 2009) en de Middellandse Zee (Lauria et al., 2015), zachte substraten, vooral zand, terwijl dat in andere gebieden zoals de Noordzee (Sguotti et al., 2016) en het Kanaal (Martin et al., 2012) en de Keltische Zee grovere sedimenttypen zijn. Dit kan te maken hebben met een andere oorzaak, zoals effect van verdringing van stekelroggen naar moeilijker bevisbare gebieden die een grover sedimenttype hebben. Hiervoor heeft Fock (2014) aanwijzingen gevonden in zijn analyse. Dit is als zodanig beknopt vermeld in Tabel B.2 en B.3.

Tabel B.3 Afgeleide waarden voor de door stekelroggen geprefereerde range van de abiotische milieufactoren die voorspellers zijn van stekelrog habitats

\begin{tabular}{|l|l|}
\hline Factoren & Waarden door stekelrog geprefereerd \\
\hline Diepte & $\begin{array}{l}\text { Brede range en leeftijdsafhankelijk: ondiep voor juvenielen en dieper (tot } 40 \mathrm{~m} \text { en } \\
\text { tot } 82 \mathrm{~m} \text { ) voor adulten. In Noordzee seizoensafhankelijk: dieper (20-35 m) gedurende } \\
\text { herfst en winter; ondieper (<20 m) gedurende voorjaar en zomer }\end{array}$ \\
\hline $\begin{array}{l}\text { Bodemschuifspanning } \\
\text { (stroming en golven) }\end{array}$ & $\begin{array}{l}\text { Brede range en leeftijdsafhankelijk van zwak (juv.) tot intermediair tot sterke } \\
\text { getijdestromingen (adulten) (Martin et al. 2012). Tussen } 0 \text { en } 1.5 \mathrm{~N} / \mathrm{m} 2 \text { (Maxwell et } \\
\text { al., 2009) }\end{array}$ \\
\hline Saliniteit & Vrij brede range inclusief 32.4-34.9 ppt, \\
\hline Watertemperatuur & $\begin{array}{l}\text { Hogere temperatuur in de range 9.5-19 }{ }^{\circ} \mathrm{C} \text {. Juvenielen prefereren hogere temp, dan } \\
\text { adulten. Anderzijds is temperatuur geen voorspeller volgens Humphries et al. (2016) }\end{array}$ \\
\hline Sediment type & $\begin{array}{l}\text { Brede range (slib, fijn zand, grof zand, gravel, kiezels) en leeftijdsafhankelijk van slib } \\
\text { en zandig (juv.) tot gravel en kiezels (ad.) en afhankelijk van visserijdruk }\end{array}$ \\
\hline
\end{tabular}

\section{Biotische factoren}

Biotische factoren die van belang zijn voor de ontwikkeling van een stekelrogpopulatie zijn:

- Voedselaanbod

- Concurrentie

- Predatie

- Parasieten en ziekten

\section{Voedsel en voedselaanbod}

Stekelroggen tot $80 \mathrm{~cm}$ eten hoofdzakelijk kreeftachtigen. Grotere roggen verschuiven hun voedselvoorkeur van benthische naar semi-pelagische prooi, en van kreeftachtigen naar vis. De roggen zijn opportunistisch in hun voedselkeuze en kunnen overschakelen van het ene naar het andere voedseltype, afhankelijk van de abundantie per seizoen. Het is onwaarschijnlijk dat de verspreiding van de soort wordt beperkt door de beschikbaarheid van hun prooi (Walker, 1996; Heessen et al., 2015).

\section{Concurrentie}

De stekelrog heeft veel meer kreeftachtigen in het dieet (79\%) dan de kleinoogrog (Raja microocellata) die in het Kanaal dezelfde diepterange bewoont en meer vis in het dieet heeft. Dit voorkomt wellicht concurrentie tussen beide soorten (Humphries et al., 2016). Daarnaast speelt het verschil in afmetingen van potentieel concurrerende roggensoorten mogelijk een rol bij de verdeling van de benutting van voedselbronnen op een fijnere schaal (Humphries et al., 2016). 


\section{Predatie, parasieten en ziekten}

Over predatoren, parasieten en ziekten van juveniele en adulte stekelroggen en de invloed die dat kan hebben op de populatieomvang in habitats van stekelroggen is naar wij weten nauwelijks iets bekend. Het is aannemelijk dat stekelroggen in ondiep water beter beschermd zijn tegen roofvissen dan in diep water.

\section{Habitatveranderingen}

Sommige veranderingen in habitat, zoals verdwijnen van ondergedoken zeegras (Zostera marina) en oppervlaktestructuur van habitat, kunnen negatief doorwerken op de gevoelige vroege levensstadia, bijvoorbeeld door het verlies aan verankering van eikapsels en bescherming tegen predatoren op juvenielen, en veranderingen in bentisch voedselaanbod voor juvenielen (Walker, 1996).

\section{Conclusies}

Het voorkomen van stekelroggen is afhankelijk van hoe de vijf abiotische omgevingsfactoren, zoals aangeduid in Tabel B. 2 en B.3, en de vier biotische omgevingsfactoren van invloed zijn. Verschillende variabelen werken interactief. De tolerantie en de voorkeur van de stekelrog voor deze factoren moet een venster opleveren waarbinnen het habitat geschikt geacht wordt voor de stekelrog. Voor de abiotische factoren is dit waarschijnlijk redelijk in kaart te brengen. Dat geldt echter niet voor de biotische factoren. Daarvoor kunnen met de huidige kennis nog geen tolerantiegrenzen worden gegeven. 
Wageningen Marine Research

T: $+31(0) 317480900$

E: marine-research@wur.nl

www.wur. $\mathrm{nl} /$ marine-research

Visitors address

- Ankerpark 271781 AG Den Helder

- Korringaweg 7, 4401 NT Yerseke

- Haringkade 1, 1976 CP IJ muiden
Wageningen Marine Research is the Netherlands research institute established to provide the scientific support that is essential for developing policies and innovation in respect of the marine environment, fishery activities, aquaculture and the maritime sector.

Wageningen University \& Research is specialised in the domain of healthy food and living environment.

\section{The Wageningen Marine Research vision:}

'To explore the potential of marine nature to improve the quality of life.'

\section{The Wageningen Marine Research mission}

- To conduct research with the aim of acquiring knowledge and offering advice on the sustainable management and use of marine and coastal areas.

- Wageningen Marine Research is an independent, leading scientific research institute.

Wageningen Marine Research is part of the international knowledge organisation Wageningen UR (University \& Research centre). Within Wageningen UR, nine specialised research institutes of Stichting Wageningen Research (a Foundation) have joined forces with Wageningen University to help answer the most important questions in the domain of healthy food and living environment. 